\title{
CAPITAL FLOWS IN ASIA
}

\author{
Takatoshi Ito
}

Working Paper 7134

http://www.nber.org/papers/w7134

\author{
NATIONAL BUREAU OF ECONOMIC RESEARCH \\ 1050 Massachusetts Avenue \\ Cambridge, MA 02138 \\ May 1999
}

This paper was presented at the NBER, "Capital Inflows to Emerging Markets Conference," February 20-21, 1998. Comments from Sebastian Edwards, Martin Feldstein, Carmen Reinhart, Dani Rodrik, Aron Tornell, and other participants of the conference were extremely helpful. All views and opinions expressed in the paper are author's and do not necessarily reflect those of the NBER or any institutions that the author is and has been affiliated with at present or in the past.

(C) 1999 by Takatoshi Ito. All rights reserved. Short sections of text, not to exceed two paragraphs, may be quoted without explicit permission provided that full credit, including $\mathbb{C}$ notice, is given to the source. 
Capital Flows in Asia

Takatoshi Ito

NBER Working Paper No. 7134

May 1999

\section{ABSTRACT}

This paper characterizes the capital flows in Asia before and after the Asian currency crisis of 1997. Differences in foreign direct investment, portfolio investment, and bank lending are emphasized. There are common factors and idiosyncratic factors to the role of capital flows in the currency crises in different countries, especially Thailand, Indonesia, and Korea where IMF programs were needed. Some lessons from the currency crises are also drawn. Some representative models that explain a currency crisis are suggested, and lessons are very different depending on models that are believed to be applicable.

Takastoshi Ito Institute of Economic Research Hitotsubashi University Kunitachi, Tokyo, 186, Japan and NBER

itointokyo@aol.com 


\section{Introduction}

It was just a few years ago that capital flows to Asian emerging markets were praised as a model for the rest of the world. A majority of capital flows to Asia took the form of foreign direct investment, as opposed to portfolio investment. Although portfolio investment is quick to come and quick to go, it is less likely, many believe, for foreign direct investment to reverse the direction. Capital flows to Asia increased investment, and increased investment contributed to achieving higher growth. Then high growth performances attracted further capital inflows. A virtuous cycle of capital flows and economic growth was indeed an important part of the Asian miracle. However, in the wake of Asian crisis, all the praises were all but disappeared. Even Asia could not withstand the shocks of volatile capital outflows caused by a sudden change in investors' expectations.

When the baht was floated on July 2,1997 , it was hardly a surprise for many foreign exchange dealers, Treasury officials and central bankers of G7, and academic economists. However, few predicted that the exchange rates would depreciate as much as it actually did, and the crisis would spread to other countries in the region, especially to Korea, in the following several months. The Asian currency crises of 1997 have been a surprise in its depth and contagion. Indonesia had been praised by the World Bank until just before the Thailand devaluation. There was little sign of trouble in Korea, until three months after the baht devaluation. There was no warning of contagion in the International Capital Markets report of 1997 (published in September 1997). The IMF financial support package was negotiated and accepted by the Thai authorities in August, followed by Indonesia in November and Korea in December. After six months, there is no clear assessment whether the contagion has stopped. It turned out that the Asian currency crisis of 1997 is broader and deeper than the Mexican peso crisis of 199495.

From the end of June to the end of December, 1997, the Indonesian rupiah depreciated more than 140 percent, while the Korean won and the Thai baht depreciated more than 80 percent, via-a-vis the U.S. dollar. Malaysian ringgit and Philippine peso depreciated about 50 percent. Even Singaporean dollar and Taiwanese dollar depreciated close to 20 percent. The least affected was the Hong Kong dollar and Chinese renminbi, both of which kept the nominal exchange rate 
to the U.S. dollar.

Stock prices in these countries have also plummeted. In the ASEAN-4 (Thailand, Malaysia, Philippines, and Indonesia) and Korea, stock prices became less than half from January to December of 1997. Withdrawal of funds from the stock market by foreign investors at least partly explains a simultaneous collapse of stock and currency markets.

These exchange rate and stock price movements reflect the strong outflow of capital from these Asian countries. Even relatively large foreign reserves, in terms of import months, were not enough in Thailand and Korea. In the case of Thailand, speculations in the forward market exhausted foreign reserves (in terms of spot-forward net positions) and in the case of Korea, refusal of rollovers to Korean commercial banks by foreign banks exhausted the "usable" Korean foreign reserves.

The Asian cases of 1997 also suggest a strong contagion. Countries in the region are most strongly affected by a currency crisis of a country. Although there are similarities among countries in crisis, differences are also pronounced. Common features include external shocks, the yen/dollar exchange rate movement and internal factors like weak banking system and large short-term borrowings. One cannot deny the possibility that a crisis in one country suddenly changes investors' mind about the prospects of other countries.

The rest of the paper is organized as follows. The next section describes how capital went into Asian from 1991 to 1996. Section 3 summarizes the crisis of 1997. Similarities and differences between Mexico and Asian countries, and also those among Asian countries will be shown. Lastly, lessons from this episode of the currency crises will be drawn in Section 4, and Section 5 concludes.

\section{Capital Flows to Asia}

\subsection{Overview}

Capital flows to Asia have been a focus of the intensive studies in the last several years, especially after the currency crisis of the 1997. Figure 1 shows the total gross capital inflows-direct investment, portfolio investment, and other capital flows (78bed, 78bgd, 78bid lines of International Financial Statistics,

IMF)— to the ASEAN-4 (Thailand, Indonesia, Philippines, and Malaysia) and 
China for the period from 1976 to 1997. Several characteristics are evident. First, capital flows to these countries increased markedly in the 1990s (until the crisis of 1997). Second, capital flows to China after 1993 dwarfs others. Third, among ASEAN countries, Thailand has been the largest recipient of capital flows between 1988 and 1996. However, with the currency crisis, they became outflows in 1997. Fourth, capital flows to Indonesia and Malaysia were larger than other countries from 1982 to 1984 , but declined since then.

Let us focus on net private capital flows in the 1990s and compare Asia with other regions. Table 1 shows global capital flows to developing and transition economies (taken from IMF, International Capital Markets). Net private capital flows to emerging markets increased seven-fold from 1990 to 1996 . In 1990, total capital flows to emerging markets (developing countries and transition economies) were about 30 billion dollars, of which two-thirds went to Asia and one third went to Latin American countries. In 1993, the total amount of capital flows was up to 160 billion dollars, of which Asia and Latin America received about 40 percent each. A majority of flows to Asia took the form of direct investment and an overwhelming portion of flows to Latin America took the form of portfolio investment. The large ratio of portfolio flows to Latin American countries in 199193 became a source of instability in the wake of, if not a trigger of, the Mexican peso crisis. In 1995, net portfolio investment to Latin America became negative in the wake of the Mexican peso crisis. The total private flows also declined sharply. Capital flows to Latin America recovered sharply only in 1996, contributing to a new record high for the capital flows to emerging markets exceeding 240 billion dollars, of which about a half went to Asia, and one third went to Latin America.

Several reasons for the sharp rise in capital flows from 1990 to 1996 have been pointed out in the literature. First, a declining trend of the interest rates in the advanced countries prompted the institutional investors to search high yield opportunities in many emerging markets. ${ }^{1}$ The pursuit of high yield was reinforced by desire to diversify their portfolio internationally. Second, on the recipient side, emerging markets liberalized restrictions on inward investment. Some developing countries introduced economic reforms including financial sectors. Others allowed direct investment into various industries. These factors are analyzed in IMF (1995). 
During the episode of strong capital inflows, several host countries complained that capital inflows were too much, in that capital inflows were causing adverse side effects, overheating domestic economies to speculative appreciation pressure. Thailand and Malaysia in particular received inflows amounting to more than 10 percent of GDP. Thailand was accumulating foreign reserves as a result of intervention to prevent appreciation even with current account deficits of 8 percent (of GDP) in 1995-96. If not intervened, the currency would have appreciated. Intervention was probably only partly sterilized. There are some signs that capital inflows contributed a real estate boom in Thailand and Malaysia. More detailed discussions on the inflow problem are found in IMF (1995).

The picture sharply changed in 1997. The Thai baht was effectively devalued in July, and the Thai government asked for the IMF assistance in August. The currency crisis spread to Indonesia, Malaysia, Philippines, and Korea in the subsequent months. Private capital fled from these countries. In the end net private capital flows to Asia fell from 110 billion dollars in 1996 to mere 14 billion dollars in 1997. Net portfolio investment to Asia became negative in 1997 for the first time since 1990. If the affected countries-Indonesia, Korea, Malaysia, the Philippines, and Thailand-were singled out, private capital went out in net by 11 billion dollars. Even in the crisis, foreign direct investment to Asia did not decline from 1996 to 1997. This reflects both investors' confidence in the long-run prospects of Asian economies and host countries willingness to be acquired in hard times. It is also notable that portfolio flows declined sharply both in the Latin American countries in 1995 and Asian economies in 1997. However, the drop in portfolio flows were much more dramatic among Latin American countries in the aftermath of the Mexican crisis.

In total of net private capital slows, the decline among Asian countries from 1996 to 1997 was much more dramatic than the decline for Latin American countries from 1994 to 1995 . There are two factors to consider. First, in the Mexican crisis of 1994-95, the crisis was effectively stopped by the IMF packages to Mexico at the end of January 1995 and to Argentina in March 1995. In contrast, the Asian currency crisis spread from Thailand, to Indonesia, to Korea. This contributed to a much larger decline in net capital flows to Asia in 1997 than to Latin America in 1995. Second, in both crises, the bank lending and credits were 
reversed sharply (see "Other" line in Table 1) among Asian economies.

\subsection{Scenario: Virtuous and Vicious Cycle}

Net capital inflows make it possible for a host country to run current account deficits without running down the foreign reserves. Net capital inflows increase resources that the host country can use. In Asia, capital inflows were mostly used for investment. The saving rate is already high in many Asian countries, especially in Malaysia and Singapore, but the investment rate is even higher. Investment, both foreign direct investment and domestic companies and government projects are believed to have contributed to higher growth. Higher growth in turn invites more investment.

One of the factors that helped exports and economic growth of the East Asian countries in the last two decades was a long-term trend of yen appreciation. There are at least two channels from yen appreciation to economic growth of the Asian economies. First, as the yen appreciates, Asian products will become more price competitive against Japanese goods in the world markets, especially in the Japanese and the U.S. markets. For example, Korean shipbuilding, steel, and semiconductors are direct competitors to Japanese counterparts in the world market. Although they may not compete directly in the same quality category, they indirectly compete in the same product category. Hence, yen appreciation is a business chance for manufacturing companies based in East and Southeast Asian economies.

Second, yen appreciation has convinced many Japanese companies of benefits in moving production facilities out of Japan. Looking for the production sites where high quality workers are available at low wages, Japanese manufacturing companies shifted production abroad, mainly in Asia. ${ }^{2}$ Technological transfers with Japanese management helped the Asian countries increase productivity in manufacturing. Some of productions in Asia became productive enough to export to the United States, Japan, and the rest of the world.

Hence, the low interest rate and the yen appreciation were external shocks to the Asian economies in 1994-96. Yen appreciation produced more Japanese direct investment in Asia. FDI from Japan and other advanced countries provided the host countries with technological transfer and export capability. Asian exports 
grew at the rate of 20 to 30 percent. Low interest rate in the industrial countries including Japan produced the portfolio flows to the Asian economies. Those portfolio flows were used investment rather than consumption. Asian economies were totally confident in their export-let growth strategy and the World Bank "East Asian miracle" gave a seal of approval.

The currency "stability" vis-à-vis the US dollar was instrumental in bringing in direct and portfolio investment. The investors had confidence in Asian countries that were virtually pegged to the US dollar. The currency risk was minimal, so considered the investors and borrowers. The credit risk was also minimal, due to high economic growth. The interest rates in the Thailand were higher than in the US, and that invited bank deposits and short-term bond investment.

Growth in one Asian country is further amplified by growth in other countries in the region, as countries are connected by trade and investment flows. The "multiplier" of growth among countries the region was considered to be rather high.

Large current account deficits in some countries were source of concern for some economists. But high economic growth made it possible to assert that the "grow-out-of-debt" scenario would work. The low total productivity growth pointed out by Young and Krugman posed some doubts on the sustainability of high growth. But, industrialization and sophistication of the industries were impressive enough to wipe off doubts. Essentially, high growth invited more capital inflows, that produced even higher exports and economic growth. This is the virtuous cycle, as schematically depicted in Figure 1. Until 1996, almost all observers were confident that the virtuous cycle would work for a foreseeable future.

The virtuous cycle was suddenly interrupted in 1996-97. Exports from most Asian countries sharply declined due to several reasons. The yen depreciation from 1995 to 1997 reduced Asian goods' competitiveness. Slow growth produced lower economic growth. However, before the crisis, it was growth recession-from 1995 to 1996, growth rates in Thailand was down from 8.8\% to 5.5\%, Malaysia from $9.5 \%$ to $8.6 \%$, Singapore from $8.7 \%$ to $6.8 \%$, and Korea from $8.9 \%$ to $7.1 \%$. On the other hand, growth was hardly affected in Indonesia, the Philippines, China, and Taiwan. 
The growth rate of Japanese FDI and portfolio flows to Asia was slowing down due to the yen depreciation, but capital flows to Asia continued to be strong, due to increased flows from Europe and the U.S. in 1996. In fact, there was not significant change in FDI and capital flows until the devaluation broke out in July 1997.

Japanese FDI, mostly assembly plants of finished products, to Asia has stimulated industrialization. However, factories built by Japanese FDI continue to require imports of parts and semifinished goods from Japan. As domestic production of parts has become a challenge for Asian countries which have recorded large trade deficits against Japan. (An exception is Indonesia which records surpluses against Japan.)

Once the currency was destabilized in July-August 1997 among ASEAN countries, capital inflows to the region became substantially cut. As discussed above, net private capital flows to the Asian region in 1997 became only one-tenth of that of 1996. Most of the outflows took place in banking flow reversal. All the logic of virtuous cycle worked in reverse. The vicious circle (Figure 2) set in after September 1997: Capital outflows caused the currency to depreciate; depreciation made the real economy and the banking sector weaker; weak economies made investors' pessimistic; and pessimism encouraged further capital outflows.

\subsection{FDI to Asia, overview}

Foreign direct investment (FDI) to Asia has increased steadily during the 1990s. Table 2 shows that FDI flows to selected Asian countries and economies measured by host countries' authorities. ${ }^{3}$

From Table 2 (Panel A), it is evident that all Asian countries significantly increased FDI inflows during the 1990s. The increases are most significant in China, where it was a 15-fold increase in six years (1990 to 1996 before the East Asian crisis). Other countries, Korea, Singapore, Indonesia, Thailand, and Viet Nam saw from two-fold to four-fold increase in the first six years of the 1990s.

Table 2, panel B, shows the source countries of FDI to Asia in 1995. Japan provided most FDI to the total of nine Asian countries (4 NIEs, ASEAN-4, and China). In some countries (Korea, Taiwan, Singapore, and Philippines), the US is the number one FDI source country, while for others, Japan is the number one. 
Europe collectively was investing into Asia in a similar size to the US. However, for most countries, impacts of FDI in typical Asian countries are dictated by investors' behavior of Japan and the United States.

As the largest investor in the region, the role of Japan in FDI is important. The Japanese FDI data to Asia is analyzed. The Japanese data are collected by the Ministry of Finance, Japan, and they are based on the voluntary (formerly mandatory) reporting basis. Table 3 shows changes in the Japanese FDI to the nine Asian economies in the 1990s. ${ }^{4}$ The Japanese FDI to the world were below 5 billion dollars a year until 1980. It became more than 10 billion dollars in 1984 . Only two years later, the amount was doubled, exceeding 22 billion dollars. It reached 67 billion dollars in 1989. In the beginning of the 1990s, FDI in fact declined to 36 billion dollars, before turning around and went back to the neighborhood of 50 billion dollars. Out of the total FDI in the postwar period, 617 billion dollars, more than half was done in the 1990s. The largest recipient is Indonesia, closely followed by Hong Kong and China. Japan invested in the NIEs (Korea, Taiwan, Singapore, and Hong Kong) during the 1980s, as well as the 1990 s - the ratio of the 1990 s investment to the all years is below 60 percent. In contrast, more than 60 percent of Japanese FDI to Thailand, Malaysia, and the Philippines were done in the 1990s, reflecting the rapid rise of these economies, and the sharp rise in Japanese investment in these economies. In the beginning of 1990s, Indonesia, Thailand, and Malaysia were the preferred destinations of Japanese FDI. On average Indonesia has received more than 150 billion yen (about 1.3 billion dollars) annually in the 1990s. By the mid-1990s, China became the top host of Japanese FDI. In 1995, China received more than 430 billion yen (about 4 billion dollars) of Japanese FDI.

Foreign direct investment (FDI) is often said to be a preferred form of investment for host countries. (Direct investment is usually defined as a purchase of more than 10 percent in equities of a particular company.) Compared with bank credit, bank deposits, or bonds, it is more difficult and costly to withdraw investment which have become factories and other real assets. Moreover, direct investment comes with foreign management and technological transfers, which is expected to contribute to improving industrialization levels of a host country. 


\subsection{FDI determinants}

According to the virtuous cycle hypotheses, FDI from Japan is motivated by optimistic expectations on the prospects of the Asian economies and the yen appreciation. The Japanese firms moved their productions to Asian economies as the yen appreciated. The level of the yen/dollar rate influences the flow of foreign direct investment from Japan to Asian countries. Figure 2 shows the correlation between the level of the yen/dollar rate and the foreign direct investment from Japan to Asian countries. ${ }^{5}$ This shows the rapid rise of FDI from 1986 to 1989, which appears to be a lagged response to the sharp yen appreciation (drop in the yen/dollar rate) from 1985 to 1988 .

In a more rigorous manner, determinants of FDI flows from Japan to Asia, in aggregate or in individual countries, can be analyzed. Suppose that FDI flows are motivated by the cost conscious Japanese manufacturing firms, then the yen/dollar exchange rate is an important signal. For each industry, there seems to be a threshold of the value of the yen. When the firm judge that the yen is persistently above the threshold, the firm moves production facility to Asia. It may take one year to convince the firm that the yen is "persistently" above a certain level, so the yen/dollar rate is lagged one period. The yen/dollar exchange rate is the determinants in deciding locations of production facilities for Japanese exporters. Most labor intensive portion of the production process was out-sourced first. The semifinished products or finished products are then exported back to Japan or other countries.

The Japanese FDI is also motivated by the prospect of the Asian economies, as some of the products are intended to be consumed locally. Japanese auto makers set up production, sometimes in joint ventures, for example in Thailand, Indonesia, and Malaysia, mainly to sell autos in their respective countries. It is mostly to avoid high tariffs of auto imports. The FDI to pursue domestic consumption is motivated by the prospect of economic growth.

With these considerations, the log of FDI flow from Japan to Asia is regressed on the log of the yen/dollar exchange rate, one year lagged, and growth rate, in aggregate or the individual countries. Unfortunately, the FDI data are only available annually, and the sample period is from 1976 to 1997 . Table 4 shows regression results. 
In the aggregate specification, the log of aggregate FDI flows from Japan to eight Asian countries (four NIEs and ASEAN-4), FDI8, is regressed on the log of the yen/dollar exchange rate of year $t-1$, and the average growth rate of these eight countries. The negative coefficient of the yen/dollar rate implies that FDI from Japan to the eight Asian economies tends to increase as the yen appreciates (drop of the yen/dollar rate). The positive coefficient of the growth rate implies that an increase in growth rates of the Asian economies tends to increase FDI from Japan to these economies.

For individual countries, the log of aggregate FDI flows from Japan to an Asian country is regressed on the log of the yen/dollar exchange rate of year (t-1), and the growth rate of year (t). Results in general confirm effects of the yen-dollar exchange rate effect and the optimistic expectation, driven by actual growth rate, on the FDI flows from Japan. In each economy, either the yen or the growth rate is statistically significant (at least at 5 percent, except for Taiwan, where only 10 percent significance) with expected signs. In Korea, the Philippines, and Malaysia, both variables are significant.

\subsection{Effects of FDI on the economy}

When foreign capital flows in as direct investment, it has at least two positive effects on the economy. First, it adds to the domestic saving to become funds for investment. Second, it often comes with technological spillovers.

There are many studies on impacts of FDI on the host country. ${ }^{6} \mathrm{~A}$ recent studies, such as Belderbos, Capannelli and Fukao (1999) and Urata and Kawai (1999), show the significant technological spillovers to the subsidiaries in Asia from the Japanese manufacturing firms. ${ }^{7}$

The growth rate of the Asian economy is regressed on the level of foreign direct investment of year (t-1), the change in the yen/dollar exchange rate, Japan's growth rate, and the US growth rate. The yen appreciation (drop in the yen/dollar rate) will enhance competitiveness of Asian exporters that compete with Japan's exporters. Therefore the change in the exchange rate will promote exports of the Asian economies, contributing to their economic growth. The coefficient of the change in the yen/dollar exchange rate is expected to be negative. The two most important markets for most Asian economies are Japan and the United States. 
Therefore, the income effects of the Japanese and the US economic growth should appear in the economic growth of Asian economies as positive coefficients on Japan's economic growth rates and the US economic growth rates. ${ }^{8}$

Our main interest here is whether the lagged FDI will increase economic growth rate, controlling for the exchange rate the economic growth rates of the two most important trading partners. The specificaiton that only FDI of year (t-1) is included assumes high dissemination of technological transfer and a temporary boost of productivity. The statistically-significant positive coefficient on the FDI term is indicative of growth-enhancing technological transfers.

Table 5 shows the regression results. For the aggregate of the 8 economies, results are consistent with theoretical predictions mentioned above. The first row shows the result for the aggregate of the eight Asian economies (4 Nies and ASEAN4). The weighted average of growth rates of the economies tends to increase when the level of FDI from Japan in the preceding year is high, implying the boost to the productivity associated with FDI. The growth rate becomes higher if the yen appreciates (a negative sign is yen appreciation) from the preceding year. Higher growth in Japan and the United States help the growth of these economies. Estimates imply that a 10 percentage point appreciation in the yen increases 0.5 percentage point of the average Asian growth rate in these economies. One percentage point increase in Japanese and US growth rates, respectively, increases the average Asian growth rate by 0.4 and 0.2 percentage point.

For individual economies, results are not as prominent as the aggregate equation. The FDI effect on growth is evident for Hong Kong, Thailand, and Malaysia. The yen/dollar exchange rate seems to influence growth in Korea, Taiwan, Thailand, and Malaysia. In these economies, 10 percentage point appreciation in the yen boost the economic growth rate by 1 percentage point. The Japanese economic growth has a positive spillover effect on Korea, Taiwan, and Thailand, while the US economic growth has a positive effect only on Taiwan. Regressions for Singapore, Indonesia, and the Philippines did not produce any meaningful result.

\subsection{Portfolio Flows}

Portfolio investment consists of equities, bonds, and other securities 
investment. Bank deposits and lending and cross-border transfers between bank branches are usually classified as "other types" of capital flows. Table 6 shows three types of gross capital flows-FDI, Portfolio, and other-to Korea, ASEAN4, and China. It is shown in the ratio (\%) to GDP so that the relative impact to the economy can be assessed. Between 1994 and 1996 (that is, after the Mexican crisis and before the Asian crisis), these countries have received large amount of capital inflows, but composition was very much different across countries.

China and Malaysia are the two countries that encouraged and received foreign direct investment. Their portfolio inflows are minimal or even negative in the case of Malaysia. Except Malaysia in 1992 and 1993, other types of capital inflows were very small too.

Thailand received most capital inflows in the ratio of GDP between 1993 and 1996. The total capital inflows were about 10 percent of GDP between 1993 and 1996 . Most notably, portfolio inflows and other types of inflows were higher than FDI. Since portfolio or other types of capital flows are considered to be much more mobile than FDI, this feature was an ominous sign of coming currency crisis, at least in retrospect. However, the precise mechanism of movement of "hot money" is debatable.

In case of Mexican crisis in December 1994, it has been argued that a sudden and massive outflows in days after the "surprise" $15 \%$ devaluation is blamed for bringing down the peso by almost 50\% in one week. Mostly, short-term securities investment, especially Tesobonos, by mutual funds and institutional investors withdrew their investment quickly. The larger size of portfolio investment is potential for such kind of a large impact of a sudden reversal of capital flows by investors, once their assessment of the country changes.

\subsection{Bank Lending}

In order to investigate further what kind of money is invested, the crossborder bank lending is investigated. Table 7, panel A shows the balance of crossborder bank lending from industrial countries to developing countries. Total liabilities and short-term liabilities of recipient countries, as of end-June 1997, are shown in the first two columns after the country names. The breakdown of total lending, by countries of lending banks, to each borrowing country is shown. In a general tendency, the Japanese and European banks lend to Asian countries, while American and European countries lend to Latin American countries. Among the 
Asian countries, Japanese banks have higher shares in Thailand (54\%), Indonesia (39\%), and Malaysia (36\%), while European banks, collectively, have more than $40 \%$ of shares in China, India, Malaysia, and Taiwan. Among the Latin American countries, US banks' share is between 20 and 28 percent, while European banks about $50 \%$.

In ratio to GDP, total bank liabilities are highest in Thailand (0.381), followed by Malaysia, Indonesia, and Korea. These countries have higher ratios of bank liabilities to GDP than any Latin American countries.

Bank lending behavior is supposedly different from securities investment. Although they are short-term, they are often lent on implicit understanding of rolling over indefinitely. If the interest rate spread is maintained, bank lending is usually rolled over. However, once banks suspect credit (default) risk becomes, overwhelming, any interest rate spread may not keep the bank lending.

In order to assess the vulnerability to potential problems with bank lending, such as a sudden refusal of roll-overs, the short-term lending to the foreign reserves is examined. The ratio of the stock of short-term liabilities to foreign reserves represents one possible measure of this type of vulnerability. If the ratio is higher than one, it implies that if all banks refuse to roll over the short-term loans, foreign reserves will be exhausted. Among Asian countries, the ratio exceeds one in Korea, Indonesia, and Thailand. These three countries needed the IMF assistance later in that year. In retrospect, this indicator would have been good in predicting the Asian currency crisis. Among Latin American countries, the ratio exceeds one in Argentina and Mexico.

In Table 7, panel $\mathbf{B}$, the changes in these bank liability indicators from 1993 to 1997. For Asian countries, bank liabilities tended to increase both for the total liability/GDP ratio and the short-liability/foreign-reserve ratio. The exception is China for the latter indicator. The cases of Thailand and Malaysia stand out in their increases in the latter indicator. Asian countries relied on bank lending for their economic development.

For Latin American countries, movements are mixed. Between 1993 and 1997, some countries increased the total liabilities to GDP ratio and the short-term liabilities to foreign reserve ratio, while other countries decreased these ratios.

The salient feature of the country share movement is the rapid expansion 
of European banks both in Asia and Latin America. In aggregate, European banks increase the share of lending to Asia by 6 percentage points, while the Japanese banks decreased lending by 8 points. In case of Latin American countries, the European banks increased its share from $45 \%$ to 50\%, while both the Japanese and US banks decreased their shares by 5 points. If the lending boom to Asia was to be blamed, which is a controversial "if," then the European banks were the ones that seemed to lay the last brick in Asia.

In China, Indonesia, Korea, Malaysia, and Taiwan, European banks increased their share markedly at the expense of Japanese banks, while in the Philippines, European banks increased their share at the expense of the United States. Only in Thailand, Japanese banks maintained a significant share.

\subsection{Too much capital flows?}

As explained in the beginning of this section, capital flows, especially FDI, are in general a part of "a virtuous cycle" in developing countries. However, an exceptionally large size of capital flows, especially short-term flows, become large, monetary policy becomes difficult. (See Khan and Reinhart (1995) is one of the first papers on this topic. See also IMF (1995).) Capital flows to Asian countries have been sometimes massive, sometimes exceeding 10 percent of GDP.

When the size of capital inflows becomes larger than current account deficits, there is an appreciation pressure on the currency. Having adopted the de facto dollar peg, many Asian countries have resisted the appreciation pressure by intervening the foreign exchange market. The stability in the exchange rate was considered to be important for nurturing exporting industries and inviting FDI inflows. As intervention continued, levels of foreign reserves among Asian countries have soared in the 1990s. Intervention can be sterilized or left unsterilized. Unsterilized intervention will increase monetary base, resulting in lower interest rates. The stimulating effect of lower interest rates may cause inflation, if the economy is already in the full capacity production, which is often the case for emerging market economies that attract a massive capital inflows.

In order to avoid inflation, intervention can be sterilized. Sterilized intervention is a combination of foreign exchange intervention and domestic open market operation to keep the monetary base constant (in levels or in proportion to 
GDP in a growing economy). Sterilized intervention will keep the interest rate level the same, in theory. In practice, the interest rate may rise by the sterilized intervention. Suppose the initial capital inflows were in the form of FDI. The domestic end of sterilization is most likely done in the short-term money market. Then, the short-term interest rate may increase, while the long-term interest rate will decline. The higher short-term interest rate will invite more capital inflows in the form of portfolio investment. Hence, sterilized intervention may increase capital inflows.

Of course, a story as told in the manner of policy decision tree, is only a reflection of the well-known economics principle: it is impossible for a small open economy to have free capital flow, the fixed exchange rate, and independent monetary policy. Usual theoretical answer to this impossibility problem is to float the exchange rate. A more heterodox answer is to adopt some mild forms of capital controls on short-term inflows, such as raising the reserve requirements on bank deposits by nonresident or imposing withholding taxes on short-term instruments held by nonresidents. Many emerging markets did adopt market-based capital controls (see IMF, 1995).

There is an important footnote to the impossibility principle. By reducing fiscal deficits (or increasing fiscal surpluses) will ease the overheating pressure by capital inflows. A contractionary impact of fiscal surpluses, such as tax increases or expenditure cut, is mitigated by monetary stimulus of unsterilized intervention. In fact, several Asian countries, such as Thailand, adopted this option in the beginning of the 1990s. Many Asian countries did run fiscal surpluses.

Lessons on the danger of too much capital inflow seems to have been learnt in the Mexican peso crisis of 1994-95. The governments of many emerging markets were vigilant on capital flows. However, the Asian countries did run into a problem in 1997. The next section analyzes what happened to capital flows in the midst of the currency crisis in Asia. 


\section{The Currency Crisis of 1997}

\subsection{Overview}

The Asian currency crisis has been analyzed in several papers and books. See Goldstein (1998), Krugman (1998), Montes (1998), Radelet and Sachs (1998a, b), to name a few. Various reasons for the currency crisis were suggested. Three factors have been identified as the major causes. First, the de facto dollar peg as the currency regime contributed to generating crisis. China, and Hong Kong have maintained the nomial fixed exchange rate to the US dollar. Before the crisis, Thailand, Singapore, Malaysia, and Korea all adopted a currency basket system. However, they in fact had a high weight on the US dollar in the basket (see Frankel and Wei (1994)), so the exchange rate regime was de facto dollar peg. In the period of yen appreciation, Asian exporters enjoy high growth contributing to an overall high economic growth, while in the period of yen depreciation, Asian economies' performance becomes less impressive. In fact, the yen depreciation from 1995 to 1997, was partly a reason for lower growth of Asian economies (except the Philippines) in 1996-1997. Moreover, the dollar peg with high interest rates invited in short-term portfolio investment. Investors and borrowers mistook the stability of the exchange rate as the nonexistence of exchange rate risk.

Second, a weak bank and nonbank sector complicated the currency crisis. Key industries of many Asian countries relied on bank lending for their fund needs. Banks in Korea were lending to industries that were deeded to be important from the industrial policy point of view. Many Indonesian banks, including one or two state banks, had been seriously burdened by nonperforming loans. Thai finance companies (nonbanks) had large nonperforming loans from an asset inflation (1992-93) and deflation (1996-97). A weak banking system becomes an indicator of for foreign speculators to attack the currency. When attacked, the central bank could employ a high interest rate policy to encourage capital to stay (or come in). But, weak banks would make this policy counterproductive from the domestic banking policy. Knowing this, speculators are more willingly to attack a country with a weak banking system. The banking crisis causes the currency crisis. Also, many bank liabilities and corporate debts were denominated in the US dollars. This was a reflection of the dollar peg. However, when the currency is devalued, dollar-denominated liabilities would become much larger in terms of the local 
currency. The currency crisis often causes the banking crisis. In this sense, the currency crisis and banking crisis are "twin crises" (Kaminsky and Reinhart (1996)).

Third, short-term liabilities were mounting in some of Asian economies, most notably in Thailand, Indonesia, and Korea (recall Tables 6 and 7). These short-term capital can be withdrawn quickly and put pressures on the exchange rate. Withdrawal of funds slowly started in Thailand in 1996 . Once the thai baht was floated, neighboring countries were on the alert list on the investors. Withdrawal of short-term funds intensified after September. Refusal of the rollover of bank loans particularly put pressure on the Korean won.

In addition to these common factors, there are idiosyncratic factors for different countries. Speculative attack by hedge funds was a trigger for the Thai de facto devaluation, while Indonesia did not intervene so that foreign reserves were ample when it asked for a "precautionary" IMF program. The burst bubble was the major cause for weak financial systems in Bangkok, while reasons other than bubbles explain the weak banking system in Seoul and Jakarta. Controls on capital accounts had been eliminated for a long time in Indonesia, while there were significant capital controls in Korea. Thailand went through financial liberalization several years prior to the currency crisis. Political conflicts were a major problem in Indonesia, while Thailand and Korea had a solid political

More detailed analysis of mine has to be left for other opportunities. (Ito $(1998 \mathrm{a}, \mathrm{b}, \mathrm{c}))$. The rest of this paper is devoted to a concise summary of the observations, emphasizing the role of capital flows and some new perspectives. What is new in this paper is to emphasize the common factors and idiosyncratic factors of Asian currency crisis. But, first, background to the crisis has to be described.

\subsection{Shift of the wind in 1995-96}

Several changes in the Asian economic performances occurred in 1996. First, exports have precipitously declined in most Asian countries. Export growth rates in 1994 and 1995 reached 20 to 30 percent in China, Korea, Singapore, Thailand, Malaysia, and Philippines. Then in 1996, exports of all countries went down sharply. Thai export growth, for example, slowed from more than 20 percent to virtually zero within a year. Korea and Taiwan suffered from a recession in the 
semiconductor industries. As the region depended on exports, the decline in exports substantially brought down economic growth. Figures 4 and 5 shows the remarkable decline in exports of NIEs and ASEAN-4 in 1996-1997. (More detailed analysis of export deceleration is done in Ito (1998b).

Second, as export growth slowed down, economic growth also faltered. Third, in some countries, such as Thailand, stock prices started to decline. All of these changes were signaling the end of a long boom. Capital flows which are sensitive to yields started to reverse the direction.

As economic growth slowed down, a virtuous cycle turned into a vicious circle (recall Figure 2). The exports decline was a trigger for a shift from a virtuous to vicious cycle.

\subsection{Thailand}

The crisis first hit Thailand, which seemed most vulnerable from traditional measures. In 1996, the current account deficits of Thailand had reached 8 percent of GDP, the same level that brought Mexico into a currency crisis in 1994. The export growth rate plummeted from 20 percent per annum to virtually zero, although a decline in the economic growth rate was only modest, from about 9 percent to 7 percent. In retrospect, Thailand experienced a bubble economy from 1993 to 1995 . The economy was overheated and stock prices soared in 1993, as capital flows increased, especially in the form of portfolio flows. (See Ito (1998c) and Nukul Report (1998).)

Note that a major slow down in exports occurred also back in 1984-85. Recall that the dollar appreciated. This supports the working hypothesis described in the previous sections that the dollar appreciation (yen depreciation) is bad for the Asian exports and growth.

After the asset bubble burst, banks in Thailand had nonperforming loans problems. In particular, finance companies borrowed from domestic and foreign banks to finance their property loans were in serious problems. The weakness in financial system, along with large current account deficits, invited speculative attacks on the baht.

The speculative attack came in several waves, between December 1996 to

the spring of 1997, before the massive speculative attack in May 1997. For one 
week in May, some investors sold the baht in the spot market, and other in the futures (or swap) market. The central bank intervened to defend the dollar peg regime, which was in place since 1984. The dollar peg was considered to be instrumental to winning confidence of foreign investors. The net result for the central bank position was to lose the foreign reserves in forward position. Although the announced, on-balance figure of the foreign reserve was close to 30 billion dollars, it would be revealed later that the amount of off-balance dollar selling futures contracts exceeded 20 billion dollars. Although the market knew that there were central bank interventions in the futures (swap) market, as a result of defending the baht from speculators, the precise number had not been known. When the central bank decided to float the currency on July 2, the market was bit surprised only for the timing.

In the case of Mexican crisis, the Mexican government had not announced the decline in foreign reserves for almost 10 months. This non-transparent practice was criticized because market discipline could not work. This was one of the major reasons that IMF introduced Special Data Dissemination Standard (SDDS). In the case of Thai case, the foreign reserves figures were correctly disclosed every month with a one-month lag for statistics collection in compliance of SDDS as one of its subscribing nations. However, it was off-balance liability which was not disclosed to the market and finally brought down the fixed exchange rate peg.

After the baht was floated, it immediately depreciated by 15 percent. Within a few weeks, Malaysia, Philippines, and Indonesia either floated or significantly widened the band. Central banks of these countries intervened occasionally, but the amount was limited.

Although the rate was floated, the baht problem was not over. The Bank of Thailand was carrying large forward positions, and commercial banks had large short-term liabilities which may not be rolled over in the following months. The market knew that the Bank of Thailand was carrying forward contracts, but the amount was not accurately known. Thailand sought liquidity assistance from Japan and the United States in vain. The Bank of Thailand introduced in May capital controls that prohibited residents to lend money to nonresidents in offshore markets. The offshore rate deviated from onshore rates in May and June, but deviations became very small after floating the rate. By the end of July, Thailand 
decided to ask for assistance from International Monetary Fund.

There were two kinds of problems in putting together an IMF program for Thailand. First, the amount of a support package would have to become large, and the limit in stand-by loans may not be enough. Second, it was not clear what kind of conditionality should be placed.

After intense negotiations, Thailand agreed to an IMF conditionality which includes tight monetary and fiscal policy, as well as concrete action programs on finance companies. The assistance program had also Japan and other Asian countries also offered assistance. IMF portion was $\$ 4$ billion dollars (close to $500 \%$ of quota for Thailand), while Asian countries, including Japan, pledged additional $\$ 13.2$ billion. ${ }^{9}$ It was a quite unusual arrangement that Japanese Export-Import Bank provided a parallel loan of $\$ 4$ billion with IMF. The agreement was signed on August 20, 1997.

One of the problems that Thailand experienced was the fragile financial system, in particular, huge nonperforming loans problems in the finance companies. In June, worst 16 finance companies were suspended. In addition, 42 finance companies were suspended before the IMF agreement of August.

The IMF program did not put an end to the depreciation of the baht. As the IMF program failed to stop depreciation of the baht, other currencies in the region became further affected.

The loss of foreign reserves was a major concern in Thailand. The termination of foreign bank lending was also a cause and effect of depreciation. Capital flows out of Thailand were accute (recall Figure 1), and they took place mostly in terms of bank lending withdrawal. (recall Table 6).

\subsection{Indonesia}

Indonesia was thought to be doing well on the macroeconomic managment. The exchange rate had flexibility (slow depreciation vis-à-vis the U.S. dollar on the slide schedule with a band around it), and intervention was restrained to conserve foreign reserves. The fundamentals were better than neighboring countries. However, toward the end of September, the Indonesian rupiah depreciated suddenly, and it was decided in Jakarta to seek IMF assistance. This decision was a little surprising in the sense that there was little evidence that the central bank 
needs to build up foreign reserves at that point. Also, problems in the Indonesian economy lie in the real sector, namely inefficient big national projects and nontransparent President's family businesses. The IMF conditionality would look quite different from a usual one.

On November 5, the IMF program was agreed. At the same time, coordinated intervention by other Asian central bank was carried out to help prop up the value of the rupiah. A most remarkable aspect of the IMF program for Indonesia was to close down (not just to suspend) sixteen banks with questionable assets. One bank was owned by President Suharto's son. Depositors were paid off only up to a certain amount. There was also no announcement on the health of the remaining banks. This caused a run on some of weak banks.

Uncertainty which was not completely resolved was the size of corporate debts to foreigners. As many firms borrowed from foreign banks (in foreign currency denomination), but the total amount was not known at the time. To Indonesia, IMF, the World Bank, and ADB decided to extend $\$ 23$ billion. The U.S., Japan, Singapore, and Asian countries pledged a "secondary line” of support.

However, having an IMF program did not stop depreciation of the rupiah. Ironically, a real currency crisis came after the IMF program was signed. In the midDecember, a rumor of President Suharto having poor health, based on his cancellation of appearance in an international conference, pushed down the rupiah. Also, whether structural reforms would be carried out was questioned, especially after a closed bank was replaced by a new bank run by the same person at the same site. After President Suharto announced a new fiscal year budget on January 6, which contained more than 40 percent increase in its size, the rupiah was sold heavily. The rate broke the level of $10,000 \mathrm{rupiah} / \$$ and went down to a point, where the rupiah's value was one-sixth of what it was a year earlier. The rupiah's movement was much more influenced by political news. In the process of rupiah depreciation, foreign investors' role was not as heavy as capital flight.

\subsection{Korea}

Korea was initially thought to be remote from a crisis. The fundamentals had turned around for better earlier this year. The exchange controls were reasonably stringent, so that it would be difficult to speculate against the won. Nonresidents cannot borrow the won. The Korean won did not depreciate more than 20 percent 
until the end of October. However, suddenly in November, the currency became under heavy pressure. Foreign banks that had lent to Korean banks decided to withdraw funds, by not rolling over their lending. Korean central bank reportedly lent foreign reserves, as foreign-currency deposits, to commercial banks, which could not raise funds without paying prohibitively high risk premium (Korean premium).

Korea decided to ask for an IMF assistance toward the end of November, and obtained one on December 4. Negotiation was carried out in an unusually fast manner. The amount of assistance was also unusually large. IMF would provide $\$ 21$ billion, supplemented by $\$ 10$ billion from the World Bank and $\$ 4$ billion from ADB. The United States, Japan, and other countries would provide additional $\$ 36$ billion, bringing the grand total of $\$ 57$ billion.

One of the most critical elements in the Korean crisis was how much would foreign banks roll over their lending to Korean banks. It was estimated that shortterm liabilities would be close to $\$ 100$ billion, if guarantees provided by the Korean corporations to their subsidiaries abroad are counted. Table 8 summarizes how Korea's external liabilities have changed.

Pressure on the won did not stop at the IMF program of December 4. Accute problems in liquidity developed surrounding Korean banks. It was not until December 24, when administrative pressure from monetary authorities of G7 was applied on commercial banks to maintain lending to Korean banks, that the crisis was contained.

Recall that the short-term bank liability to foreign reserve ratio was highest in Korea (Table 7). The Korean currency crisis can be understood in terms of "bank run," (in terms of Radelet and Sachs (1998a, b)) unlike Thailand or Indonesia.

\subsection{Contagion}

The experience of Asian currency crises in 1997 certainly puts more weights on the case of contagion. In the case of the Mexican peso crisis, the tequila effect did not

succeed in changing the exchange rate regime, despite pressures on Argentina, and Asian countries. However, in the case of Asian currency crises, depreciation spread to a large number of countries. 
An interesting work would be whether a contagion model, such as Eichengreen and Rose would have predicted such spillovers, at the point that Thailand decided to float. How much increase in probability of devaluation in rupiah, ringgit, and Philippine peso would the Thai devaluation of July 2 would have indicated? When investigated closely, a contagion process was more complicated than just spillovers from Thailand. Through the summer and up to September, the Thai baht was most depreciated, followed by rupiah, peso and ringgit. However, from October to November, the degrees of depreciation for baht and ringgit are about the same, near 40 percent. Up to November, the Korean won depreciated only about 15 to 20 percent. As a crisis in Seoul deepens, the won depreciated further. The process indicates that the direction of spillovers change over time. This was not the case in a simple devaluation-led crisis like Mexico 1994.

Recall the hanges in the currencies of NIEs and ASEAN-4. From July to October, the baht was the most depreciated currency. Other ASEAN currencies were following the movement of the baht. The magnitude of the peso, ringgit, and rupiah depreciation was about half of the baht depreciation until September. Then, rupiah suddenly depreciated at the end of September. From September to November, the rupiah movement seems to influence other currencies. Then, the Korean won depreciated sharply in December, reflecting the liquidity problem mentioned above. Indonesian rupiah depreciated further in January 1998. Therefore, sources of contagion seem to shift from one country to another, as political and economic shocks occur in various countries. 


\section{Lessons: Capital Flows and Reversal ${ }^{10}$}

Many reasons for the capital inflows and their subsequent reversal have been suggested. Depending on which reason is to be believed, a prescription to prevent a future crisis will be different. We will review some of the current thinking on the issue.

\subsection{Moral hazard}

A first hypothesis is that capital flows to Asia can be characterized as the result of moral hazard. Some observers pointed out that implicit guarantee of deposits and financial institutions by emerging market invite too much capital flows. (Goldstein (1997, 1998), Krugman (1998), McKinnon and Pill (1996)) Investors perceive that deposits that pay higher interest rates than the advanced countries attractive, and especially so when the economy is growing fast and the exchange rate stability appears to be secured. Mexico before 1994 and Thailand before 1997 are primary examples. The host countries receive capital which cannot be put into productive use which has longrun returns exceeding the interest rates that are paid to creditors. Mexico resulted in a consumption boom and Thailand a real estate boom. Investors remained complacent just before the crisis because they felt that investment are protected by the government guarantee. In case of Mexico, a large part of capital inflows were explicitly guaranteed because they were government securities (tesobonos). In case of Thailand, capital flows that rapidly rose in 1994 to 1997 were through its offshore banking facility (BIBF). In this case, investors must have recognized that deposits were implicitly guaranteed because the government would bail out banks, just like in advanced countries. Moreover, investors may be reassured by the IMF handling of Mexico in 1995, because investors were not asked to involuntarily roll over their investment. Borrowers were also mistaken. They might not be placing capital in a prudent manner. They tend to go for a high-risk, high-return project. If the project fails, the government would bail out the bank, and if the project succeeds, the bank benefits. The situation is well known in the deposit insurance literature. Explicit and implicit guarantees caused the moral hazard among investors and borrowers.

If moral hazard is the problem, there are two kinds of solution. First, prudential regulation on borrowers to avoid building the dangerous positions is important. Second, burden sharing on lenders, once a problem develops, would deter future irresponsible lenders.

One problem with this argument, however, is the timing of crisis. Why the capital inflows reversed in 1997 so dramatically cannot be explained adequately from 
moral hazard. If the blanket guarantee was to be believed, there is no reason for investors to flee so quickly.

Another problem with the moral hazard explanation is the cross-sectional differences. Why Indonesia and Korea were affected most severely, while the Philippines and Malaysia seem to have escaped the worst. The blanket guarantees were the same for Asia, and other macroeconomic fundamentals were similar. Moral hazard argument alone would not explain the cross-sectional differences.

One way to combat the moral hazard problem is to ask the involved parties to take losses from easy lending and borrowing. Many observers point out the problem of moral hazard on the part of borrowers. However, overborrowing is overlending. How could IMF ask "lenders" (Tesobonos. Lenders to 58 finance companies in Thailand. ) to take losses? In fact, IMF packages are usually strict enough that countries do not willingly come under, and the penalty of mismanagement is severe, negative economic growth for Mexico and Thailand after the crisis. There is little scope for moral hazard on the part of a country to mess up the economy (at least for a decade or two after one crisis). IMF did not "bail out the country", because money was repaid in the Mexican case, and so will the Asian cases. What IMF packages bail out in the Mexican type crises is actually a group of lenders to the countries, by recovering the asset values (currency, stock, Tesobonos, Brady bond, and other bond prices). If Mexican Tesobonos holders had been asked to take some losses in the Mexican peso crisis, they might not have extended too much credit to some of the Asian countries that got into trouble in 1997. It would be difficult to devise a program to ask for a fair share of burdens on lenders, without causing an international systemic risk, unless the IMF intervenes swiftly.

Another solution is to strengthen prudential regulations. Thailand relaxed banking regulations and capital controls without strengthening bank supervision. Finance companies were outside of more strict bank regulation. A lack of policy contributed to easy lending. Korean merchant banks were outside the bank regulation which restricted a large lending to a single customer. A lesson here is that fianancial deregulation has to be accompanied by strengthening bank and nonbank supervision.

\subsection{Bank run}

Radelet and Sachs (1998a,b) argue that the Asian currency crises were caused by sudden shift in investors' behavior. Those countries that relied on short-term capital 
inflows were caught in the liquidity crisis when investors refused to roll over lending. In the case of the Mexican crisis of 1994-95, it was the short-term government securities (tesobonos) which became a focus of the roll-over problem. In Thailand and Korea, domestic banks could not obtain enough dollars to repay short-term borrowings when roll-overs were refused. Banks were not insolvent, by any standard. It was a liquidity problem, or a problem of bank run (a la Diamond-Dybvig (1983)).

When a currency crisis of a country is analyzed in the model of bank run, investors' behavior to withdraw funds form the country may not have to be irrational. Given other creditors are withdrawing funds, it is rational to withdraw funds. In fact, it is rational to be first in line.

The situation in Korea in November and December 1997 fits the bank run model best. Korean banks faced acute liquidity shortage in US dollars, and the monetary authorities helped them with providing the foreign reserves (as deposits to commercial banks). When foreign reserves are exhausted, there was no choice but to ask for the IMF assistance.

If the bank run is the sole reason for the crisis, establishing the international lender of last resort would be a good solution. Suppose that the International Monetary Fund to play the role of international lender of last resort. The IMF would inject foreign reserves, and the central bank would help commercial banks unwind the liability positions, when roll-overs are refused. In fact, having the lender of last resort would convince lenders not to refuse roll over. This is a straight-forward application of the role of domestic central bank to the international circumstances.

If analogy to the domestic central bank is applicable, the IMF lending to help prevent a bank run should not be tied to a stringent conditionanality, and disbursement has to be quick and front-loaded.

The reservation to such an international lender of last resort also comes from the analogy to the domestic central bank. In order to provide liquidity in a massive amount, the monetary authorities regularly conduct strict examinations. Weak institutions are closed or at least restricted in their activities. When a liquidity crisis occurs, the monetary authorities have to have a confidence that that financial institutions are essentially sound before it injects liquidity to help financial institutions. Similarly, the monetary authorities of the emerging markets have to demonstrate that the liquidity support from the international lender of last resort does not go into insolvent institutions. Therefore any recommendation for establishing the international lender of last resort should be accompanied by the proposal to 
strengthening the banking system and its supervision. Moreover, in practice, it is often very difficult to distinguish the liquidity problem from the insolvency problem.

A possible solution to an international bank run is to make IMF the international lender of last resort. Funding would have to be increased and conditionality would have to be relaxed. It might be necessary to create a regional fund to which neighboring countries subject to possible contagion supplement the IMF coffer.

\subsection{Herd Behavior}

Similar to the idea of bank run, the model of herd behavior has been developed in the finance literature. In relation to stock market crashes, Scharfstein and Stein (1990) and Banerjee (1992) developed the so-called herd behavior model. Investors behave in a herd because it is profit maximizing to behave as others do. When others are investing, it is more likely that prices will go up and the currencies to appreciate, so that it makes sense to invest. When others are withdrawing, it is rational to go along because prices and currencies would go down. The self-fulfilling prophecy works.

One might question this kind of simple story by arguing that markets have a self-regulating mechanism which would bring the economy back to the equilibrium. A currency depreciation shock by capital flows should promote exports and thus in the long-run put the pressure to appreciate the currency. For example, depreciation would hurt the balance sheet of banks and corporations that borrowed in foreign currencies. Thus, lending from banks would be limited and the interest rate would rise. The business activities would be depressed and struggle to obtain working capital. The depressed domestic demand, consumption and investment, further depress the business activities.

In the meantime, if the inflation rate increases due to the depreciated currencies, the real exchange rate does not warrant much increase in exports. Foreign debts (denominated in nominal terms in foreign currencies) are mushroomed in local currencies.

The fate of the Indonesia seems to fit this description of herd behavior and multiple equilibria well. How else could we explain that the economy is still suffering (at minus $15 \%$ growth rate) at the exchange rate level that is one-sixth of pre-crisis level? Other countries, such as Thailand and Korea, also have negative growth, even though their currencies have depreciated by $30-40 \%$.

Herd behavior can be dealt with by capital controls, or a stand-still agreement 
imposed by IMF. Temporary capital controls on outflows may calm the market. A stand-still agreement that would be an effective tool to start negotiation process of corporate debts or sovereign bonds. This would eliminate the incentive to withdraw funds first.

\subsection{Irrational exuberance and a bubble}

The last model is more ad hoc. Excessive capital inflows can be characterized by irrational exuberance (a famous word of Alan Greenspan on US stock prices), which sooner or later results in an eventual crash. The stock prices and real estate prices of some Asian cities, like Thailand, Hong Kong, and Kuala Lumpur, increased so high due to the capital inflows, which were prompted by high economic growth. However, at least in the end, the level of stock prices could not be rationalized by fundamentals. The stories of real estate bubbles in some Asian cities were similar to those in Japan, the bubble and burst cycle from 1985 to 1998. Ito and Iwaisako (1996) explained the stock price movements by applying the stochastic bubble model, a la Blanchard and Watson (1982). A similar methodology can be applied to the Asian crisis.

\subsection{Early Warning Signal}

It has become a popular exercise to look for variables that help predict a future crisis. Frankel and Rose (1996), Eichengreen and Rose (1996), Goldstein (1996), Kaminsky, Lizondo, and Reinhart (1997) have contributed to the literature of early warning signals. Frankel and Rose (1996) identified, for example, the size of current account deficits and the composition of bank borrowing (short-term and foreign-currency-denominated loans), increases the probability of a future crisis (large devaluation). Goldstein (1996) list seven factors as presumptive indicators of vulnerability to a financial crisis: an upturn in international interest rates; a mismatch between the government's/banking system's short-term liabilities and its liquid assets; a large current account deficits; an overvalued exchange rate; weak banking system and large fiscal deficits which put constraints on the authorities' willingness to increase interest rates; a boom in bank lending followed by a fall in asset prices; and high susceptibility to contagion due to similarities to a financial crisis elsewhere (more likely if neighboring countries). Eichengreen and Rose also confirms a contagion effect, that is, a probability of a crisis increases if a

neighboring country experiences a crisis. Kaminsky, et al. (1997) attempted to 
calculate appropriate widths of thresholds of various macro variables. When an indicator moves beyond certain threshold levels, they are treated as a signal. On any given month, the system would estimate the probability of a crisis within the following 24 months conditional on the indicators issuing signals at that moment. The variables are chosen on the basis of indicating correct signals (while minimizing false signals) for a crisis. Although the results are encouraging, there are as many false signals as correct signals even for variables that are less noisy.

\section{Concluding Remarks}

In this paper, characteristics of capital flows in Asia before and after the crisis of 1997 were summarized. Although some common factors are available, each crisis has its own idiosyncratic factors. In fact, Thailand, Indonesia, and Korea present much different kinds of "food for thought," just as their ethnic foods are different. Thailand is much like a classic attack on the reserve for a country with large current account deficits, while Korea seems to be an international bank run. Indonesian problem cannot be understood without investigating political and social shocks. These differences reflect underlying bank and corporate liability structures, which is a result of their policies during the capital inflow phase. The capital outflow crisis investigation has to start at research on capital inflows. For this reason, detailed data analyses and description of idiosyncratic factrors in this paper may be useful for further research. 


\section{References}

Belderbos, Rene; Giovanni Capannelli, and Kyoji Fukao, 1999. "Local Procurement by Japanese Electronics Firms in Asia" in T. Ito and A. O. Krueger, Role of Foreign Direct Investment in Economic Development, NBER, University of Chicago Press, forthcoming.

Banerjee, Abhijit, 1992. "A Simple Model of Herd Behavior," Quarterly Journal of Economics, vol. CVII: 797-817.

Blanchard, Olivier and Mark W. Watson, 1982. "Bubbles, Rational Expectations, and financial markets," in P. Wachtel, (ed) Crisis in the Economic and Financial Structure, Lexington Books.

Diamond, Douglas, and P. Dybvig. 1983. Bank runs, deposit insurance and liquidity, Journal of Political Economy, vol. 91: 401-419.

Eichengreen Barry and Portes Richard 1995 Crisis What Crisis Orderly Workouts for Sovereign Debtors London: Center for Economic Policy Research

Eichengreen, Barry and Andrew Rose, 1996. "Contagious Currency Crises: Channels of Transmission," in T. Ito and A. O. Krueger (eds.) Changes in Exchange Rates in Rapidly Developing Countries: Theory, Practice, and Policy Issues, NBER-University of Chicago Press.

Frankel, Jeffrey A. and Andrew K. Rose, 1996. "Currency Crashes in Emerging Markets: Empirical Indicators,” NBER working paper 5437, January.

Frankel, Jeffrey A. and S.-J. Wei, 1994. "Yen Bloc or Dollar Bloc? Exchange Rate Policies of the East Asian Economies," in Ito, T. and A. O. Krueger (eds.) Macroeconomic Linkage: Savings, Exchange Rates, and Capital Flows, University of Chicago Press.

Goldstein, Morris, 1996. "Presumptive Indicators/Early Warning Signals of Vulnerability to Financial Crises in Emerging-Market Economies," Institute for International Economics, photocopy, January.

Goldstein, Morris, 1997. The Case for an International Banking Standard, Institute for International Economics, Washington, DC.

Goldstein, Morris, 1998. The Asian Financial Crisis: Causes, Cures, and Systemic Implications, Institute of International Economics, Washington, DC.

Graham, Edward M. and Paul R. Krugman, 1991. Foreign Direct Investment in the United States, Second Edition, Institute of International Economies, Washington, DC, 1991.

Graham, Edward M. and Paul R. Krugman, 1993. "The Surge in Foreign Direct Investment in the 1980s" in Kenneth A. Froot (ed) Foreign Direct Investment, NBER, University of Chicago Press.

Group of Ten 1996. "The Resolution of Sovereign Liquidity Crises" photocopy, May. 
International Monetary Fund 1995 International Capital Markets: Developments Propects and Policy Issues Washingtont DC: International Monetary Fund

International Monetary Fund 1996 International Capital Markets: Developments Propects and Policy Issues Washingtont DC: International Monetary Fund

Ito, Takatoshi, 1998a. "Bail-out, Moral Hazard, and Credibility: IMF and World Bank policies in Crises of the 21st century type," presented at the Wharton conference on Asian Twin Financial Crises, Tokyo, March 10.

Ito, Takatoshi, 1998b. "Asian Exports: Principal Causes of Deceleration," mimeo Asian Development Bank.

Ito, Takatoshi, 1998c. "The Development of the Thailand Currency Crisis: A Chronological Review," The Japan Export-Import Bank, RIID Review, vol. 24, September: 66-93.

Ito, Takatoshi; Eiji Ogawa; and Yuri Nagataki Sasaki, 1988. "How did the dollar peg fail in Asia?" Journal of the Japanese and International Economies, vol. 12, no. 4: forthcoming.

Ito, Takatoshi and Tokuo Iwaisako, 1996. "Explaining asset bubbles in Japan" Monetary and Economic Studies, Bank of Japan, vol. 14, July: 143-193.

Kaminsky, Graciela L., Saul Lizondo, and Carmen M. Reinhart, 1998. "Leading Indicators of Currency Crises," IMF Staff papers

Kaminsky, Graciela L. and Carmen M. Reinhart, 1996. "The Twin Crises: The Causes of Banking and Balance-of-Payments Problems," Board of Governors of the Federal Reserve System, photocopy, February.

Khan Mohsin S. and Carmen M. Reinhart, 1995. "Macroeconomic Management in APEC Economies: The Response to Capital Inflows", in M. S. Khan and C. M. Reinhart (eds.) Capital Flows in the APEC Region, IMF Occasional Paper, no. 122, pp. 15-30.

Kojima, Kiyoshi, 1978. Direct Foreign Investment, London: Croom Helm.

Krugman, Paul, 1979. "A Model of Balance-of-Payments Crises" Journal of Money, Credit, and Banking, vol. 11, no. 3, August, pp. 311-325.

Krugman, Paul, 1985. "Is the Strong Dollar Sustainable?" in Federal Reserve Bank of Kansas City, The U.S. Dollar-Recent Developments, Outlook, and Policy Options, 1985, chapter 5: pp. 103-155.

Krugman, Paul, 1998. “What Happened to Asia?” January.

McKinnon, Ronald, and Hugh Pill, 1996. "Credible liberalizations and international capital flows: the overborrowing syndrome," in T. Ito and A.O.Krueger, eds., Financial Deregulation and Integration in East Asia, Chicago: Chicago University Press. 
Milesi-Ferretti, G. M. and A. Razin, 1996a. Current-Account Sustainability, Princeton Studies in International Finance, no. 81, October 1996.

Milessi-Ferretti, G. M. and A. Razin, 1996b. "Persistent Current Account Deficits: A Warming Signal?" International Journal of Finance \& Economics, vol. 1, no. 3, July: 161-182.

Montes, Manuel F., 1998. The Currency Crisis in Southeast Asia, Updated Edition, Institute of Southeast Asian Studies.

Nukul Commission, 1998. "Analysis and Evaluation on Facts Behind Thailand's Economic Crisis," (translated by Nation Multimedia Group, Thailand).

Radelet, Steven and Jeffrey Sachs, 1998a, "The Onset of the East Asian Financial Crisis," presented at a seminar at USAID, January 29, 1998; and NBER Currency Crises Conference, February 6-7, 1998.

[Bank run model]

Radelet, Steven and Jeffrey Sachs, 1998b. "The East Asian Financial Crisis: Diagnosis, Remedies, Prospects," Brookings Panel, Washington DC March 26-27, 1998.

[criticism of IMF Policy]

Scharfstein, David and Jeremy Stein, 1990. "Herd Behavior and Investment," American Economic Review, vol. 80, June: 465-479.

Urata, Shujiro, and Hiroki Kawai, 1999. "Foreign Direct Investment and International Technology Transfer in East Asia: The Case of Japanese Manufacturing Firms," in T. Ito and A.O. Krueger, Role of Foreign Direct Investment in Economic Development, NBER University of Chicago Press. 
Table 1. Net Private Capital Flows to Emerging Markets

Unit, billion U.S. dollars

\begin{tabular}{|c|c|c|c|c|c|c|c|c|}
\hline 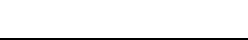 & 1990 & 1991 & 1992 & 1993 & 1994 & 1995 & 1996 & 1997 \\
\hline $\begin{array}{l}\text { Emerging } \\
\text { markets, } \\
\text { Total } \\
\quad \text { FDI } \\
\quad \text { Portfolio } \\
\quad \text { Others } \\
\end{array}$ & $\begin{array}{c}31.0 \\
17.6 \\
17.1 \\
-3.7\end{array}$ & $\begin{array}{c}126.9 \\
\mathbf{3 1 . 3} \\
\mathbf{3 7 . 3} \\
\mathbf{5 8 . 4}\end{array}$ & $\begin{array}{c}120.9 \\
37.2 \\
59.9 \\
23.8\end{array}$ & $\begin{array}{c}164.7 \\
60.6 \\
103.5 \\
0.7\end{array}$ & $\begin{array}{c}160.5 \\
84.3 \\
87.8 \\
-11.7\end{array}$ & $\begin{array}{c}192.0 \\
96.0 \\
23.5 \\
72.5\end{array}$ & $\begin{array}{c}240.8 \\
114.9 \\
49.7 \\
76.2\end{array}$ & $\begin{array}{c}173.7 \\
138.2 \\
42.9 \\
-7.3\end{array}$ \\
\hline $\begin{array}{l}\text { 1. Asia } \\
\text { Total } \\
\text { FDI } \\
\text { Portfolio } \\
\text { Others }\end{array}$ & $\begin{array}{c}19.1 \\
8.9 \\
-1.4 \\
11.6\end{array}$ & $\begin{array}{c}35.8 \\
14.5 \\
1.8 \\
19.5\end{array}$ & $\begin{array}{c}21.7 \\
16.5 \\
9.3 \\
-4.1\end{array}$ & $\begin{array}{c}57.6 \\
35.9 \\
21.6 \\
0.1\end{array}$ & $\begin{array}{c}66.2 \\
46.8 \\
9.5 \\
9.9\end{array}$ & $\begin{array}{l}95.8 \\
49.5 \\
10.5 \\
35.8\end{array}$ & $\begin{array}{c}110.4 \\
57.0 \\
13.4 \\
39.9\end{array}$ & $\begin{array}{c}13.9 \\
57.8 \\
-8.6 \\
-35.4\end{array}$ \\
\hline $\begin{array}{l}\text { 1a. Affected } \\
\text { Total } \\
\text { FDI } \\
\text { Portfolio } \\
\text { Others }\end{array}$ & $\begin{array}{c}24.9 \\
6.2 \\
1.3 \\
17.4\end{array}$ & $\begin{array}{c}29.0 \\
7.2 \\
3.3 \\
18.5\end{array}$ & $\begin{array}{c}30.3 \\
8.6 \\
6.3 \\
15.4\end{array}$ & $\begin{array}{c}32.6 \\
8.6 \\
17.9 \\
6.1\end{array}$ & $\begin{array}{c}35.1 \\
7.4 \\
10.6 \\
17.1\end{array}$ & $\begin{array}{c}62.9 \\
9.5 \\
14.4 \\
39.0\end{array}$ & $\begin{array}{l}72.9 \\
12.0 \\
20.3 \\
40.6\end{array}$ & $\begin{array}{c}-11.0 \\
9.6 \\
11.8 \\
-32.3\end{array}$ \\
\hline $\begin{array}{l}\text { 2.LatinAmeric } \\
\text { a } \\
\text { Total } \\
\text { FDI } \\
\text { Portfolio } \\
\text { Others }\end{array}$ & $\begin{array}{c}10.1 \\
6.7 \\
17.5 \\
-14.0\end{array}$ & $\begin{array}{c}26.1 \\
11.0 \\
14.7 \\
0.3\end{array}$ & $\begin{array}{l}56.0 \\
13.6 \\
30.4 \\
12.0\end{array}$ & $\begin{array}{l}64.3 \\
12.8 \\
61.1 \\
-9.5\end{array}$ & $\begin{array}{r}47.4 \\
24.3 \\
60.6 \\
-37.5\end{array}$ & $\begin{array}{r}35.7 \\
25.3 \\
-0.1 \\
10.5\end{array}$ & $\begin{array}{l}\mathbf{8 0 . 5} \\
\mathbf{3 6 . 9} \\
\mathbf{2 5 . 2} \\
\mathbf{1 8 . 5}\end{array}$ & $\begin{array}{r}91.1 \\
51.2 \\
33.5 \\
6.5\end{array}$ \\
\hline $\begin{array}{l}\text { 3.Transition } \\
\text { Economies, } \\
\text { Total } \\
\text { FDI } \\
\text { Portfolio } \\
\text { Others } \\
\end{array}$ & $\begin{array}{r}3.5 \\
-0.3 \\
0.0 \\
3.7 \\
\end{array}$ & $\begin{array}{r}-2.4 \\
2.4 \\
0.0 \\
-4.8 \\
\end{array}$ & $\begin{array}{l}7.2 \\
4.2 \\
0.1 \\
2.9 \\
\end{array}$ & $\begin{array}{c}12.2 \\
6.0 \\
4.5 \\
1.7 \\
\end{array}$ & $\begin{array}{c}18.4 \\
5.4 \\
4.1 \\
8.9 \\
\end{array}$ & $\begin{array}{c}29.8 \\
13.2 \\
2.9 \\
13.6 \\
\end{array}$ & $\begin{array}{c}21.3 \\
13.1 \\
2.9 \\
13.6 \\
\end{array}$ & $\begin{array}{c}34.5 \\
18.2 \\
7.3 \\
9.0 \\
\end{array}$ \\
\hline $\begin{array}{l}\text { 3.Other } \\
\text { regions } \\
\text { Total } \\
\text { FDI } \\
\text { Portfolio } \\
\text { Others } \\
\end{array}$ & $\begin{array}{r}-1.7 \\
2.2 \\
1.1 \\
-5.0\end{array}$ & $\begin{array}{c}67.4 \\
3.5 \\
20.7 \\
43.3\end{array}$ & $\begin{array}{c}36.0 \\
5.9 \\
16.3 \\
8.4\end{array}$ & $\begin{array}{c}\mathbf{3 0 . 6} \\
5.9 \\
16.3 \\
8.4\end{array}$ & $\begin{array}{c}28.5 \\
7.9 \\
13.7 \\
7.0\end{array}$ & $\begin{array}{c}30.7 \\
7.9 \\
10.2 \\
12.5\end{array}$ & $\begin{array}{c}28.7 \\
7.9 \\
8.9 \\
11.8\end{array}$ & $\begin{array}{l}34.3 \\
11.0 \\
10.8 \\
12.6\end{array}$ \\
\hline
\end{tabular}

Notes. "Others" include short- and long-term credits, loans (not including use of IMF credit), currency and deposits, and other accounts receivable and payable.

"Other regions" include "Middle East and Europe" and "Africa".

"Latin America" is labeled as "Western Hemisphere" in the original table.

Source, IMF, International Capital Market September 1998. 
Table 2: Gross Foreign Direct Investment Inflows

Panel A. Time-series of FDI inflows

US\$million

\begin{tabular}{|c|c|c|c|c|c|c|c|c|}
\hline & 1990 & 1991 & 1992 & 1993 & 1994 & 1995 & 1996 & 1997 \\
\hline China & 3500 & 4400 & 11000 & 27500 & 33800 & 37500 & 42400 & 45300 \\
\hline Korea & 803 & 1396 & 895 & 1044 & 1317 & 1941 & 3203 & 6971 \\
\hline Taiwan & 2302 & 1778 & 1461 & 1213 & 1631 & 2925 & 2461 & 4267 \\
\hline $\begin{array}{l}\text { Singapor } \\
\text { e }\end{array}$ & 1224 & 1425 & 1678 & 1966 & 2833 & 3423 & 4054 & 3979 \\
\hline $\begin{array}{l}\text { Indonesi } \\
\mathbf{a}\end{array}$ & 8751 & 8778 & 10323 & 8144 & 23724 & 39915 & 29931 & 33833 \\
\hline $\begin{array}{l}\text { Thailan } \\
\text { d }\end{array}$ & 8029 & 4988 & 10022 & 4285 & 5875 & 16492 & 13124 & 10616 \\
\hline Malaysia & 6517 & 6202 & 6975 & 2443 & 4321 & 3652 & 6812 & 4018 \\
\hline $\begin{array}{l}\text { Philippin } \\
\text { es }\end{array}$ & 961 & 778 & 284 & 520 & 2374 & 1871 & 967 & $\overline{1993}$ \\
\hline $\begin{array}{l}\text { Viet } \\
\text { Nam }\end{array}$ & 512 & 1147 & 1926 & 2615 & 3722 & 6524 & 8497 & 5550 \\
\hline
\end{tabular}

Source: Economic Planning Agency, Japan, Asian Economies 1998 (in Japanese), 1998.

Original Sources: Government Agencies of host countries.

Panel B. Cross-section by source country, 1995

\begin{tabular}{|c|c|c|c|c|c|c|c|c|c|c|}
\hline \$mil. & $\begin{array}{l}\text { Korea } \\
95\end{array}$ & $\begin{array}{l}\text { Taiw } \\
\text { an } \\
94\end{array}$ & $\begin{array}{l}\mathrm{HK} \\
95\end{array}$ & $\begin{array}{l}\text { China } \\
95\end{array}$ & $\begin{array}{l}\text { Sing } \\
\text { apor } \\
\text { e95 }\end{array}$ & $\begin{array}{l}\text { Mala } \\
\text { ysia } \\
94\end{array}$ & $\begin{array}{l}\text { Phil } \\
\text { ipp } 9 \\
5\end{array}$ & $\begin{array}{l}\text { Thai } \\
\text { land } \\
95\end{array}$ & $\begin{array}{l}\text { Indone } \\
\text { sia95 }\end{array}$ & TOTAL \\
\hline TOTAL & $\begin{array}{r}914 . \\
4\end{array}$ & $\begin{array}{r}1523 \\
.9\end{array}$ & 566 & $\begin{array}{r}37520 . \\
5\end{array}$ & $\begin{array}{r}4852 \\
.4\end{array}$ & $\begin{array}{r}4242 \\
.5\end{array}$ & 1871 & $\begin{array}{r}1649 \\
2\end{array}$ & $\begin{array}{r}39914 \\
7\end{array}$ & $\begin{array}{r}108897 \\
.4\end{array}$ \\
\hline US & 644.9 & $\begin{array}{r}293 . \\
7\end{array}$ & 198 & 3083 & $\begin{array}{r}2075 \\
.8\end{array}$ & $\begin{array}{r}473 . \\
6\end{array}$ & $\begin{array}{r}627 \cdot 9 \\
9\end{array}$ & $\begin{array}{r}2582 \\
.2\end{array}$ & 2770.5 & $\begin{array}{r}12749 . \\
6\end{array}$ \\
\hline Japan & 418.3 & 391 & $\begin{array}{r}514 . \\
1 \\
\end{array}$ & 3108.5 & $\begin{array}{r}1152 \\
.5 \\
\end{array}$ & $\begin{array}{r}667 . \\
1 \\
\end{array}$ & $\begin{array}{r}101 \cdot \\
2\end{array}$ & $\begin{array}{r}7891 \\
.4\end{array}$ & 3792 & $\begin{array}{r}18036 . \\
1 \\
\end{array}$ \\
\hline Ger & 44.6 & 91.5 & & 386.4 & & $\begin{array}{r}247 . \\
6\end{array}$ & 0.9 & $\begin{array}{r}174 . \\
7 \\
\end{array}$ & 1344.6 & 2290.3 \\
\hline UK & 86.7 & 29.2 & $\begin{array}{r}- \\
85.5\end{array}$ & 914.1 & & 35.5 & 125 & $\begin{array}{r}301 \cdot \\
8\end{array}$ & 6322.1 & 7728.9 \\
\hline Franc & 35.2 & 15.5 & & 287 & & 18.9 & & 26.2 & 498.4 & 881.2 \\
\hline Italy & & & & 263.3 & & 20 & & 49.6 & 22.8 & 355.7 \\
\hline $\begin{array}{l}\text { Netherla } \\
\text { nd }\end{array}$ & 170.1 & 79.9 & 34.7 & 114.1 & & 12.1 & 5.6 & & 360 & 776.5 \\
\hline Swiss & 9.8 & & $\begin{array}{r}- \\
39.6 \\
\end{array}$ & 63.5 & 13.2 & & & $\begin{array}{r}100 . \\
3\end{array}$ & 44.9 & 192.1 \\
\hline $\begin{array}{l}\text { other } \\
\text { EU }\end{array}$ & & 0 & & & & & & 37.2 & 345.5 & 382.7 \\
\hline $\begin{array}{l}\text { EU } \\
\text { total }\end{array}$ & 346.4 & $\begin{array}{r}216 . \\
1\end{array}$ & $\begin{array}{r}- \\
90.4 \\
\end{array}$ & 2028.4 & 13.2 & $\begin{array}{r}334 . \\
1\end{array}$ & $\begin{array}{r}131 \cdot \\
5\end{array}$ & $\begin{array}{r}689 . \\
8 \\
\end{array}$ & 8938.3 & $\begin{array}{r}12607 \\
4\end{array}$ \\
\hline Others & 504.8 & $\begin{array}{r}623 . \\
1\end{array}$ & $\begin{array}{r}- \\
55.7 \\
\end{array}$ & $\begin{array}{r}29300 . \\
6\end{array}$ & $\begin{array}{r}1610 \\
.9\end{array}$ & $\begin{array}{r}2767 \\
.7 \\
\end{array}$ & $\begin{array}{r}1010 \\
.4\end{array}$ & $\begin{array}{r}5328 \\
.6\end{array}$ & $\begin{array}{r}24413 . \\
9\end{array}$ & 65504 \\
\hline
\end{tabular}

Notes: Based on each country's direct investment figures. China's figure is based on disbursement basis. Others are on the approval basis.

Original Source: Government Agencies of host countries. 
Source: Economic Planning Agency, Keizai Bunseki

(The Economic Analysis), no. 156, "Applied General Equilibrium Analysis of Current Global Issues - APEC, FDI, New Regionalism and Environment" (by Kanemi Ban, et al.), March 1998.

Excel, FDI Asia CrsSection 
Table 3: FDI from Japan, Time-series cum cross-country Unit, million dollars

\begin{tabular}{|c|c|c|c|c|c|c|c|c|c|c|c|}
\hline nil $\$$ & 1990 & 1991 & 1992 & 1993 & 1994 & 1995 & 1996 & 1997 & $\begin{array}{l}90- \\
97 \\
\text { tota } \\
1\end{array}$ & $\begin{array}{l}51- \\
97 \\
\text { tota } \\
1\end{array}$ & $\begin{array}{l}90 s \\
\left(\frac{\circ}{0}\right)\end{array}$ \\
\hline TOTAL & $\begin{array}{r}5691 \\
1 \\
\end{array}$ & $\begin{array}{r}4158 \\
4\end{array}$ & $\begin{array}{r}3413 \\
8\end{array}$ & $\begin{array}{r}3602 \\
5\end{array}$ & $\begin{array}{r}4105 \\
1\end{array}$ & \begin{tabular}{r|}
5147 \\
8
\end{tabular} & \begin{tabular}{r|}
4810 \\
1
\end{tabular} & $\begin{array}{r}5402 \\
5\end{array}$ & $\begin{array}{r}633 \\
12\end{array}$ & $\begin{array}{r}\begin{array}{r}6172 \\
06\end{array} \\
\end{array}$ & 58. \\
\hline Asia & 7054 & 5936 & 6425 & 6637 & 9699 & $\begin{array}{r}1238 \\
0\end{array}$ & $\begin{array}{r}1163 \\
4 \\
\end{array}$ & $\begin{array}{r}1219 \\
4\end{array}$ & \begin{tabular}{|r|}
7195 \\
8
\end{tabular} & $\begin{array}{r}1124 \\
23\end{array}$ & $\begin{array}{r}64 . \\
0\end{array}$ \\
\hline $\begin{array}{l}\text { malaysi } \\
a\end{array}$ & 725 & 880 & 704 & 800 & 742 & 576 & 573 & 792 & 5792 & 8298 & 69. \\
\hline $\begin{array}{l}\text { singapo } \\
\text { re }\end{array}$ & 840 & 613 & 670 & 644 & 1054 & 1187 & 1117 & 1826 & 7951 & \begin{tabular}{r|}
1366 \\
4 \\
\end{tabular} & 58. \\
\hline $\begin{array}{l}\text { thailan } \\
\text { d }\end{array}$ & 1154 & 807 & 657 & 578 & 719 & 1242 & 1406 & 1869 & 8432 & \begin{tabular}{r|}
1170 \\
1
\end{tabular} & $\begin{array}{r}72 . \\
1\end{array}$ \\
\hline $\begin{array}{l}\text { indones } \\
\text { ia } \\
\end{array}$ & 1105 & 1193 & 1676 & 813 & 1759 & 1608 & 2419 & 2517 & \begin{tabular}{r|}
1308 \\
9 \\
\end{tabular} & \begin{tabular}{r|}
2352 \\
4 \\
\end{tabular} & $\begin{array}{r}55 . \\
6\end{array}$ \\
\hline $\begin{array}{l}\text { philipp } \\
\text { ines }\end{array}$ & 258 & 203 & 160 & 207 & 668 & 719 & 560 & 524 & 3299 & 4620 & 71. \\
\hline $\begin{array}{l}\text { hong } \\
\text { kong }\end{array}$ & 1785 & 925 & 735 & 1238 & 1133 & 1149 & 1489 & 696 & 9150 & \begin{tabular}{r|}
1721 \\
5
\end{tabular} & 53. \\
\hline taiwan & 446 & 405 & 292 & 292 & 278 & 456 & 522 & 450 & 3141 & 5427 & 57. \\
\hline korea & 284 & 260 & 225 & 245 & 400 & 450 & 416 & 443 & 2723 & 6577 & 41. \\
\hline China & 349 & 579 & 1070 & 1691 & 2565 & 4485 & 2515 & 1989 & $\begin{array}{r}1524 \\
3 \\
\end{array}$ & $\begin{array}{r}1771 \\
6 \\
\end{array}$ & 86. \\
\hline
\end{tabular}

Notes: Foreign direct investment (FDI) from Japan in this statistics is on the "reporting basis," of cross-border investment. It may not match with actual disbursement because some reported investment may be canceled, and some will be carried out without reporting (no penalty). New FDI financed locally or reinvestment from past FDI is not covered by this statistics. FDI numbers are announced in the yen after 1995. They are converted in the dollar using the average exchange rate of the year.

Source: Ministry of Finance, Japan, (1997). Annual Report of the International Finance, 1999, Tokyo (forthcoming).

Excel file, FDI from Japan, pt 3 
Table 4: Determinants of FDI

Estimates, (T-statistics) and [significance level]

\begin{tabular}{|c|c|c|c|c|c|}
\hline $\begin{array}{l}\text { Dependent } \\
\text { Variable }\end{array}$ & Constant & Trend & $\begin{array}{l}\log (\operatorname{Yen}(t- \\
1))\end{array}$ & $\begin{array}{l}\text { Growth } \\
\text { [of } \\
\text { respective } \\
\text { economy] }\end{array}$ & $\begin{array}{l}\text { R bar sq. } \\
\text { D.W. }\end{array}$ \\
\hline Log(FDI8) & $\begin{array}{l}12.439 \\
(3.02) \\
{[0.003]} \\
\end{array}$ & $\begin{array}{l}0.058 \\
(1.38) \\
{[0.168]} \\
\end{array}$ & $\begin{array}{l}-1.111 \\
(-1.71) \\
{[0.087] *} \\
\end{array}$ & $\begin{array}{l}\mathbf{0 . 0 6 8} \\
(2.41) \\
{[0.015] * *} \\
\end{array}$ & $\begin{array}{l}\text { R=0.86 } \\
D W=1.65\end{array}$ \\
\hline $\begin{array}{l}\text { Log(FDIKor } \\
\text { Korea } \\
\end{array}$ & $\begin{array}{l}10.842 \\
(2.50) \\
{[0.013]}\end{array}$ & $\begin{array}{l}0.024 \\
(0.58) \\
{[0.013]}\end{array}$ & $\begin{array}{l}-1.335 \\
(-1.83) \\
{[0.068]}\end{array}$ & $\begin{array}{l}\mathbf{0 . 1 2 8} \\
(\mathbf{7 . 1 8}) \\
{[0.000] * * *}\end{array}$ & $\begin{array}{l}\text { R=0.74 } \\
D W=1.55\end{array}$ \\
\hline $\begin{array}{l}\text { Log(FDITai } \\
\text { Taiwan }\end{array}$ & $\begin{array}{l}4.534 \\
(1.32) \\
{[0.186]}\end{array}$ & $\begin{array}{l}0.147 \\
(4.33) \\
{[0.000]}\end{array}$ & $\begin{array}{l}-0.397 \\
(-0.67) \\
{[0.500]}\end{array}$ & $\begin{array}{l}0.069 \\
(1.87) \\
{[0.061] *}\end{array}$ & $\begin{array}{l}\text { R=0.81 } \\
\text { DW=0.59 } \\
(\mathrm{AR})\end{array}$ \\
\hline $\begin{array}{l}\text { Log(FDIhon } \\
\text { Hong Kong }\end{array}$ & $\begin{array}{l}12.854 \\
(2.98) \\
{[0.003]}\end{array}$ & $\begin{array}{l}\text { 0.056 } \\
(1.33) \\
{[0.184]}\end{array}$ & $\begin{array}{l}-1.425 \\
(-2.03) \\
{[0.042] * *}\end{array}$ & $\begin{array}{l}0.010 \\
(0.18) \\
{[0.855]}\end{array}$ & $\begin{array}{l}R=0.68 \\
D W=0.96 \\
(A R)\end{array}$ \\
\hline $\begin{array}{l}\text { Log(FDIsin) } \\
\text { Singapore }\end{array}$ & $\begin{array}{l}15.820 \\
(2.76) \\
{[0.006]} \\
\end{array}$ & $\begin{array}{l}0.022 \\
(0.46) \\
{[0.643]} \\
\end{array}$ & $\begin{array}{l}-1.915 \\
(-1.99) \\
{[0.047] * *}\end{array}$ & $\begin{array}{l}-0.027 \\
(-1.38) \\
{[0.169]}\end{array}$ & $\begin{array}{l}\text { R=0.81 } \\
D W=1.44 \\
(\mathrm{AR})\end{array}$ \\
\hline $\begin{array}{l}\text { Log(FDITha } \\
\text { Thailand }\end{array}$ & $\begin{array}{l}6.520 \\
(1.52) \\
{[0.129]}\end{array}$ & $\begin{array}{l}0.164 \\
(4.00) \\
{[0.000]}\end{array}$ & $\begin{array}{l}-0.880 \\
(-1.25) \\
{[0.213]}\end{array}$ & $\begin{array}{l}0.146 \\
(4.26) \\
{[0.000] * * *}\end{array}$ & $\begin{array}{l}\text { R=0.92 } \\
\text { DW=2.02 }\end{array}$ \\
\hline $\begin{array}{l}\text { Log(FDIInd } \\
\text { Indonesia }\end{array}$ & $\begin{array}{l}\mathbf{5 . 6 7 3} \\
(\mathbf{0 . 6 5 )} \\
{[0.515]}\end{array}$ & $\begin{array}{l}0.057 \\
(0.66) \\
{[0.509]}\end{array}$ & $\begin{array}{l}-0.156 \\
(-0.11) \\
{[0.912]}\end{array}$ & $\begin{array}{l}\mathbf{0 . 1 4 5} \\
(2.37) \\
{[0.012] * *}\end{array}$ & $\begin{array}{l}R=0.36 \\
D W=1.95\end{array}$ \\
\hline $\begin{array}{l}\text { Log(FDIPhi } \\
\text { Philippines }\end{array}$ & $\begin{array}{l}\text { 30.05 } \\
(4.38) \\
{[0.000]}\end{array}$ & $\begin{array}{l}-0.101 \\
(-1.70) \\
{[0.089]}\end{array}$ & $\begin{array}{l}-4.604 \\
(-3.98) \\
{[0.000] * * *}\end{array}$ & $\begin{array}{l}-0.060 \\
(-1.95) \\
{[0.051] *}\end{array}$ & $\begin{array}{l}R=0.86 \\
D W=2.16\end{array}$ \\
\hline $\begin{array}{l}\text { Log(FDIMal } \\
\text { Malaysia }\end{array}$ & $\begin{array}{l}-8.392 \\
(-1.37) \\
{[0.172]}\end{array}$ & $\begin{array}{l}0.260 \\
(4.54) \\
{[0.000]}\end{array}$ & $\begin{array}{l}1.804 \\
(1.80) \\
{[0.072] *}\end{array}$ & $\begin{array}{l}0.132 \\
(4.27) \\
{[0.000] * * *}\end{array}$ & $\begin{array}{l}\text { R=0.84 } \\
D W=1.81\end{array}$ \\
\hline
\end{tabular}

Sample period, 1976:1 - 1996:1.

Estimations is executed by RATS with the "Robusterrors" option, using a consistent covariance matrix allowing for heteroscedasticity and autocorrelation (LAGS=2), when necessary (when low DW, shown as "AR", with sample 1997:1 -1996:1).

FDI8=the sum of FDI from Japan to four NIEs and ASEAN-4.

$\log ($ Yen $)=\log$ of the yen/dollar rate, average of the year.

Growth rate $=$ Growth rate of the respective economy of the equation. In the case of FDI8, the growth rate is the weighted avearge of growth rates of the 
eight economies, with nominal GDP in dollars as weights, in percent. 
Table 5: Impacts of FDI on growth rate

Estimates, (T-statistics) and [significance level]

\begin{tabular}{|c|c|c|c|c|c|c|}
\hline $\begin{array}{l}\text { Dependen } \\
\text { t variable }\end{array}$ & $\begin{array}{l}\text { Constan } \\
\text { t }\end{array}$ & $\begin{array}{l}\log (F D I x(t- \\
1)) \\
x=\text { country }\end{array}$ & YenChg & Japangr & USgr & $\begin{array}{ll}\mathbf{R} & \text { bar } \\
\text { sq } & \\
\text { DW } & \\
\end{array}$ \\
\hline Asia8gr & $\begin{array}{l}0.422 \\
(0.20) \\
{[0.838]}\end{array}$ & $\begin{array}{l}\text { 0.589 } \\
(2.30) \\
{[0.021]^{* *}}\end{array}$ & $\begin{array}{l}-\mathbf{0 . 0 5 8} \\
(-3.25) \\
{[0.001]^{* * *}}\end{array}$ & $\begin{array}{l}\mathbf{0 . 3 6 1} \\
(\mathbf{3 . 0 2}) \\
{[0.003]^{* * *}}\end{array}$ & $\begin{array}{l}\mathbf{0 . 2 3 7} \\
(3.41) \\
{[0.001]^{* * *}}\end{array}$ & $\begin{array}{l}R=0.14 \\
D W=1.79\end{array}$ \\
\hline $\begin{array}{l}\text { Korea } \\
\text { Growth }\end{array}$ & $\begin{array}{l}0.603 \\
(0.13) \\
{[0.212]} \\
\end{array}$ & $\begin{array}{l}0.827 \\
(1.25) \\
{[0.212]} \\
\end{array}$ & $\begin{array}{l}-0.080 \\
(-2.36) \\
{[0.018]^{* *}}\end{array}$ & $\begin{array}{l}\mathbf{0 . 4 4 5} \\
(1.98) \\
{[0.048] * *}\end{array}$ & $\begin{array}{l}0.468 \\
(1.19) \\
{[0.235]}\end{array}$ & $\begin{array}{l}R=0.14 \\
D W=1.89\end{array}$ \\
\hline $\begin{array}{l}\text { Taiwan } \\
\text { Growth }\end{array}$ & $\begin{array}{l}\mathbf{5 . 5 9 8} \\
(2.95) \\
{[0.003]}\end{array}$ & $\begin{array}{l}-0.241 \\
(-0.77) \\
{[0.442]}\end{array}$ & $\begin{array}{l}-\mathbf{0 . 1 1 6} \\
(-3.99) \\
{[0.000]^{* * *}}\end{array}$ & $\begin{array}{l}0.474 \\
(2.15) \\
{[0.032]^{* *}}\end{array}$ & $\begin{array}{l}\mathbf{0 . 4 9 7} \\
(4.18) \\
{[0.000]^{* * *}}\end{array}$ & $\begin{array}{l}R=0.51 \\
D W=2.7 \\
4\end{array}$ \\
\hline $\begin{array}{l}\text { Hongkong } \\
\text { Growth }\end{array}$ & $\begin{array}{l}\mathbf{1 6 . 9 4 5} \\
(4.68) \\
{[0.000]} \\
\end{array}$ & $\begin{array}{l}-1.813 \\
(-4.05) \\
{[0.000]^{* * *}}\end{array}$ & $\begin{array}{l}-0.035 \\
(-0.66) \\
{[0.512]} \\
\end{array}$ & $\begin{array}{l}0.113 \\
(0.40) \\
{[0.686]} \\
\end{array}$ & $\begin{array}{l}0.268 \\
(0.98) \\
{[0.327]} \\
\end{array}$ & $\begin{array}{l}R=0.25 \\
D W=2.15\end{array}$ \\
\hline $\begin{array}{l}\text { Singapore } \\
\text { Growth }\end{array}$ & $\begin{array}{l}\mathbf{8 . 9 2 5} \\
(2.79) \\
{[0.005]}\end{array}$ & $\begin{array}{l}-0.056 \\
(-0.14) \\
{[0.890]}\end{array}$ & $\begin{array}{l}0.073 \\
(1.17) \\
{[0.238]} \\
\end{array}$ & $\begin{array}{l}-0.216 \\
(-0.55) \\
{[0.585]}\end{array}$ & $\begin{array}{l}0.097 \\
(0.57) \\
{[0.566]} \\
\end{array}$ & $\begin{array}{l}\mathrm{R}=-\mathbf{0 . 1 7} \\
\mathrm{DW}=1.32\end{array}$ \\
\hline $\begin{array}{l}\text { Indonesia } \\
\text { Growth }\end{array}$ & $\begin{array}{l}9.173 \\
(1.24) \\
{[0.215]}\end{array}$ & $\begin{array}{l}-0.352 \\
(-0.35) \\
{[0.720]}\end{array}$ & $\begin{array}{l}0.021 \\
(0.73) \\
{[0.460]}\end{array}$ & $\begin{array}{l}-0.175 \\
(-0.72) \\
{[0.469]}\end{array}$ & $\begin{array}{l}0.141 \\
(0.54) \\
{[0.590]}\end{array}$ & $\begin{array}{l}\mathrm{R}=-0.21 \\
\mathrm{DW}=1.22\end{array}$ \\
\hline $\begin{array}{l}\text { Thailand } \\
\text { Growth }\end{array}$ & $\begin{array}{l}-1.250 \\
(-0.66) \\
{[0.508]}\end{array}$ & $\begin{array}{l}1.108 \\
(3.88) \\
{[0.000]^{* * *}}\end{array}$ & $\begin{array}{l}-0.078 \\
(-1.68) \\
{[0.092]^{*}} \\
\end{array}$ & $\begin{array}{l}\mathbf{0 . 7 9 5} \\
(\mathbf{3 . 4 0 )} \\
{[0.001]^{* * *}}\end{array}$ & $\begin{array}{l}0.117 \\
(0.70) \\
{[0.482]} \\
\end{array}$ & $\begin{array}{l}\mathrm{R}=0.32 \\
\mathrm{DW}=1.00\end{array}$ \\
\hline $\begin{array}{l}\text { Malaysia } \\
\text { Growth }\end{array}$ & $\begin{array}{l}2.690 \\
(1.30) \\
{[0.193]} \\
\end{array}$ & $\begin{array}{l}\mathbf{0 . 8 8 8} \\
(\mathbf{3 . 0 6}) \\
{[0.002]^{* * *}} \\
\end{array}$ & $\begin{array}{l}0.102 \\
(2.42) \\
{[0.015]^{* *}} \\
\end{array}$ & $\begin{array}{l}0.061 \\
(0.24) \\
{[0.810]} \\
\end{array}$ & $\begin{array}{l}0.008 \\
(0.06) \\
{[0.951]} \\
\end{array}$ & $\begin{array}{l}R=0.16 \\
D W=1.24\end{array}$ \\
\hline $\begin{array}{l}\text { Philippine } \\
\text { s } \\
\text { Growth }\end{array}$ & $\begin{array}{l}0.953 \\
(0.25) \\
{[0.803]}\end{array}$ & $\begin{array}{l}0.270 \\
(0.37) \\
{[0.710]}\end{array}$ & $\begin{array}{l}-0.012 \\
(-0.16) \\
{[0.875]}\end{array}$ & $\begin{array}{l}0.497 \\
(1.09) \\
{[0.276]}\end{array}$ & $\begin{array}{l}-0.388 \\
(-0.68) \\
{[0.493]}\end{array}$ & $\begin{array}{l}R=-0.18 \\
D W=0.95\end{array}$ \\
\hline
\end{tabular}

Note: YenChg is the percent change of the yen rate change from year (t-1) to year (t). Japangr is the growth rate of Japan, and Usgr is the growth rat of the United States. 
Table 6,

Import from file "table2" 
Table 7: Cross-border Bank Lending

Panel A. June 1997

\begin{tabular}{|c|c|c|c|c|c|c|c|}
\hline \begin{tabular}{|l} 
Internati \\
1997
\end{tabular} & ional & $\mathrm{k}$ Lend & 9 to & Lected & merging & $g \mathrm{ma}$ & s, June \\
\hline $\begin{array}{r}\text { End of } \\
\text { June }\end{array}$ & $\begin{array}{l}\text { Total } \\
\text { liabil }\end{array}$ & $\begin{array}{l}\text { By } \\
\text { maturity }\end{array}$ & \begin{tabular}{|lr} 
By $\mathrm{n}$ \\
lendin \\
\end{tabular} & $\begin{array}{l}\text { ational } \\
\text { g banks }\end{array}$ & ity & $\begin{array}{l}\text { Total/ } \\
\text { GDP (96) }\end{array}$ & \begin{tabular}{|l} 
Short/ \\
Foreig
\end{tabular} \\
\hline 1997 & $\begin{array}{l}\text { ity } \\
\text { (US\$mi } \\
1 \text { ) }\end{array}$ & $\begin{array}{l}\text { Short: Up } \\
\text { to } 1 \text { yr }\end{array}$ & Japan & US & Europe & & $\begin{array}{l}\mathrm{n} \\
\mathrm{Re} \text { serv } \\
\mathrm{e}\end{array}$ \\
\hline China & 57922 & 30137 & $32 \%$ & $5 \%$ & $48 \%$ & 0.071 & 0.234 \\
\hline Indonesia & 58726 & 34661 & $39 \%$ & $8 \div$ & $38 \div$ & 0.265 & 1.629 \\
\hline Korea & 103432 & 70182 & $23 \%$ & $10 \div$ & $35 \%$ & 0.213 & 2.106 \\
\hline Malaysia & 28820 & 16268 & $36 \%$ & $8 \div$ & $44 \%$ & 0.293 & 0.609 \\
\hline $\begin{array}{l}\text { Philippin } \\
\text { es }\end{array}$ & 14115 & 8293 & $15 \%$ & $20 \div$ & $48 \%$ & 0.162 & 0.726 \\
\hline Taiwan & 25163 & 21966 & $12 \%$ & $10 \div$ & $57 \%$ & 0.092 & 0.243 \\
\hline Thailand & 69382 & 45567 & $54 \%$ & $6 \div$ & $28 \%$ & 0.381 & 1.411 \\
\hline ASIA & 389441 & 242273 & $32 \%$ & $8 \%$ & $40 \div$ & & \\
\hline Argentina & 44445 & 23891 & $4 \%$ & $23 \div$ & 59\% & 0.158 & 1.303 \\
\hline Brazil & 71118 & 44223 & $7 \%$ & $23 \%$ & $45 \%$ & 0.096 & 0.772 \\
\hline Chile & 17573 & 7615 & $8 \%$ & $23 \div$ & $51 \%$ & 0.146 & 0.447 \\
\hline Colombia & 16999 & 6698 & $8 \%$ & $20 \%$ & $59 \%$ & 0.105 & 0.674 \\
\hline Mexico & 62072 & 28226 & $7 \%$ & $28 \%$ & $43 \%$ & 0.185 & 1.187 \\
\hline \begin{tabular}{|l} 
Latin \\
America
\end{tabular} & 251086 & 131304 & $6 \%$ & $24 \%$ & $50 \%$ & & \\
\hline
\end{tabular}

Panel B. Comparison of 1993 and 1997

\begin{tabular}{|c|c|c|c|c|c|c|c|c|c|c|}
\hline & \multicolumn{2}{|c|}{$\begin{array}{l}\text { Total liability/ } \\
\text { GDP }\end{array}$} & \multicolumn{2}{|c|}{$\begin{array}{l}\text { Short liability/ } \\
\text { Foreign Reserve }\end{array}$} & \multicolumn{2}{|c|}{$\begin{array}{l}\text { Japan } \\
\text { share (\%) }\end{array}$} & \multicolumn{2}{|c|}{$\begin{array}{l}\text { US share } \\
(\%)\end{array}$} & \multicolumn{2}{|c|}{$\begin{array}{l}\text { Europe } \\
\text { Share }(\%)\end{array}$} \\
\hline & 1993 & 1997 & 1993 & 1997 & 1993 & 1997 & 1993 & 1997 & 1993 & 1997 \\
\hline China & 0.047 & 0.071 & 0.509 & 0.234 & $40 \%$ & $32 \%$ & $2 \%$ & $5 \%$ & $36 \%$ & $48 \%$ \\
\hline $\begin{array}{l}\text { Indonesi } \\
\text { a }\end{array}$ & 0.192 & 0.265 & 1.622 & 1.629 & $55 \%$ & $39 \%$ & $8 \%$ & $8 \%$ & $27 \%$ & $38 \%$ \\
\hline Korea & 0.119 & 0.213 & 1.397 & 2.106 & $30 \%$ & $23 \%$ & $10 \%$ & $10 \%$ & $33 \%$ & $35 \%$ \\
\hline Malaysia & 0.166 & 0.293 & 0.210 & 0.609 & $41 \%$ & $36 \%$ & $10 \%$ & $8 \%$ & $34 \%$ & $44 \%$ \\
\hline $\begin{array}{l}\text { Philippi } \\
\text { nes }\end{array}$ & 0.108 & 0.162 & 0.499 & 0.726 & $17 \%$ & $15 \%$ & $44 \%$ & $20 \%$ & $32 \%$ & $48 \%$ \\
\hline Taiwan & 0.069 & 0.092 & 0.175 & 0.243 & $27 \%$ & $12 \%$ & $16 \%$ & $10 \%$ & $41 \%$ & $57 \%$ \\
\hline Thailand & 0.207 & 0.381 & 0.733 & 1.411 & $55 \%$ & $54 \%$ & $8 \%$ & $6 \%$ & $24 \%$ & $28 \%$ \\
\hline ASIA & & & & & $40 \%$ & $32 \%$ & $9 \%$ & $8 \%$ & $34 \%$ & $40 \%$ \\
\hline $\begin{array}{l}\text { Argentin } \\
\text { a }\end{array}$ & 0.107 & 0.158 & 1.193 & 1.303 & $7 \%$ & $4 \%$ & $32 \%$ & $23 \%$ & $49 \%$ & $59 \%$ \\
\hline Brazil & 0.118 & 0.096 & 0.930 & 0.772 & $17 \%$ & $7 \%$ & $17 \%$ & $23 \%$ & $43 \%$ & $45 \%$ \\
\hline Chile & 0.227 & 0.146 & 0.557 & 0.447 & $9 \%$ & $8 \%$ & $33 \%$ & $23 \%$ & $42 \%$ & $51 \%$ \\
\hline Colombia & 0.140 & 0.105 & 0.433 & 0.674 & $17 \%$ & $8 \%$ & $28 \%$ & $20 \%$ & $31 \%$ & $59 \%$ \\
\hline Mexico & 0.138 & 0.185 & 1.029 & 1.187 & $7 \%$ & $7 \%$ & $35 \%$ & $28 \%$ & $42 \%$ & $43 \%$ \\
\hline $\begin{array}{l}\text { Latin } \\
\text { America }\end{array}$ & & & & & $10 \%$ & $6 \%$ & $28 \%$ & $24 \%$ & $45 \%$ & $50 \%$ \\
\hline $\begin{array}{l}\text { Notes: Eu } \\
\text { Netherland }\end{array}$ & & & & & & erm & & Iy, & uxe & $\begin{array}{l}\text { urg, } \\
\text { are }\end{array}$ \\
\hline
\end{tabular}




\begin{tabular}{|c|c|c|c|c|c|c|c|c|c|c|}
\hline \multicolumn{10}{|c|}{ Table 8: Korea's External Liability, Korea, Residents' external liabilities } & \\
\hline & \multicolumn{4}{|c|}{ Short term liabilities } & \multicolumn{5}{|c|}{ Long term liabilities } & \multirow{2}{*}{$\begin{array}{l}\text { Grand } \\
\text { total }\end{array}$} \\
\hline & $\begin{array}{l}\text { Korean } \\
\text { Banks }\end{array}$ & $\begin{array}{l}\text { Foreign } \\
\text { bank } \\
\text { branches }\end{array}$ & $\begin{array}{l}\text { Korean } \\
\text { corporati } \\
\text { ons }\end{array}$ & Total & $\begin{array}{l}\text { Korean } \\
\text { banks }\end{array}$ & $\begin{array}{l}\text { Foreign } \\
\text { bank } \\
\text { branches }\end{array}$ & $\begin{array}{l}\text { Korean } \\
\text { corporati } \\
\text { ons }\end{array}$ & $\begin{array}{l}\text { Public } \\
\text { sector }\end{array}$ & Total & \\
\hline $\begin{array}{l}\text { De. } \\
96\end{array}$ & 65.2 & 12.8 & 22.0 & 100.0 & 41.5 & 3.2 & 13.6 & 2.4 & 60.7 & 160.7 \\
\hline $\begin{array}{l}\text { De. } \\
97\end{array}$ & 37.4 & 17.2 & 25.6 & 80.2 & 40.4 & 3.8 & 17.6 & 11.0 & 72.8 & 153.0 \\
\hline
\end{tabular}

Korea, External Liabilities to International Banks, by length of maturities

\begin{tabular}{|l|l|l|l|l|}
\hline & Total & $\begin{array}{l}\text { Maturities } \\
\text { Up to and } \\
\text { equal to 1 } \\
\text { year }\end{array}$ & $\begin{array}{l}\text { Maturities } \\
\text { Over \& \& up } \\
\text { to 2 years }\end{array}$ & $\begin{array}{l}\text { Maturities } \\
\text { Over 2 years }\end{array}$ \\
\hline June 1996 & $\mathbf{8 8 , 0 2 7}$ & 62,332 & 3,438 & 13,434 \\
\hline Dec 1996 & $\mathbf{9 9 , 9 5 3}$ & 67,506 & 4,107 & 15,884 \\
\hline June 1997 & 103,432 & $\mathbf{7 0 , 1 8 2}$ & 4,139 & 16,366 \\
\hline
\end{tabular}

Source: Bank for International Settlements, "The Maturity, Sectoral and nationality Distribution of International Bank Lending," Basle, January 1998.

Korea, External Liabilities to International Banks, by lending bank nationalities

\begin{tabular}{|l|l|l|l|c|c|l|l|r|}
\hline & Total & Japan & US & Grmny & $\begin{array}{l}\text { Franc } \\
\text { e }\end{array}$ & UK & Belg. & Neth. \\
\hline Jun 96 & $\mathbf{8 8 , 0 2 7}$ & $\mathbf{2 2 , 5 1 2}$ & $\mathbf{9 , 5 8 2}$ & $\mathbf{8 , 5 2 9}$ & $\mathbf{6 , 9 9 4}$ & $\mathbf{4 , 1 4 0}$ & $\mathbf{2 , 3 1 2}$ & $\mathbf{1 , 6 5 1}$ \\
\hline Dec 96 & $\mathbf{9 9 , 9 5 3}$ & $\mathbf{2 4 , 3 2 4}$ & $\mathbf{9 , 3 5 5}$ & $\mathbf{9 , 9 7 7}$ & $\mathbf{8 , 8 8 7}$ & $\mathbf{5 , 6 4 3}$ & $\mathbf{3 , 7 3 1}$ & $\mathbf{1 , 9 2 6}$ \\
\hline Jun 97 & $\begin{array}{l}\mathbf{1 0 3 , 4 3} \\
\mathbf{2}\end{array}$ & $\mathbf{2 3 , 7 3 2}$ & $\mathbf{9 , 9 6 4}$ & $\mathbf{1 0 , 7 9 4}$ & $\mathbf{1 0 , 0 7 0}$ & $\mathbf{6 , 0 6 4}$ & $\mathbf{3 , 8 9 9}$ & $\mathbf{1 , 7 3 6}$ \\
\hline
\end{tabular}

Source: Bank for International Settlements, "The Maturity, Sectoral and nationality Distribution of International Bank Lending,” Basle, January 1998. 


\section{Figure 1.}

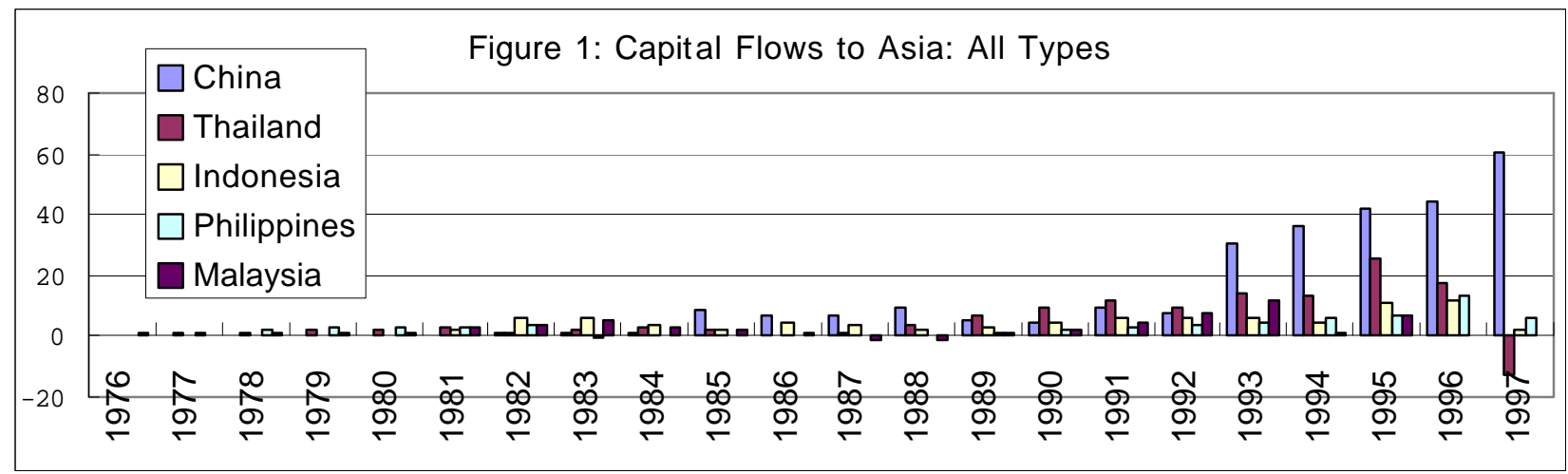

Notes: The sum of lines 78bed, 78bgd, and 78bid of the countries.

Source: IMF, International Financial Statistics, CD ROM, September 1998 
Figure 2 Capital Inflow Phase, 1990-95

\section{External Factors}

\section{Low interest rate Yen appreciation}

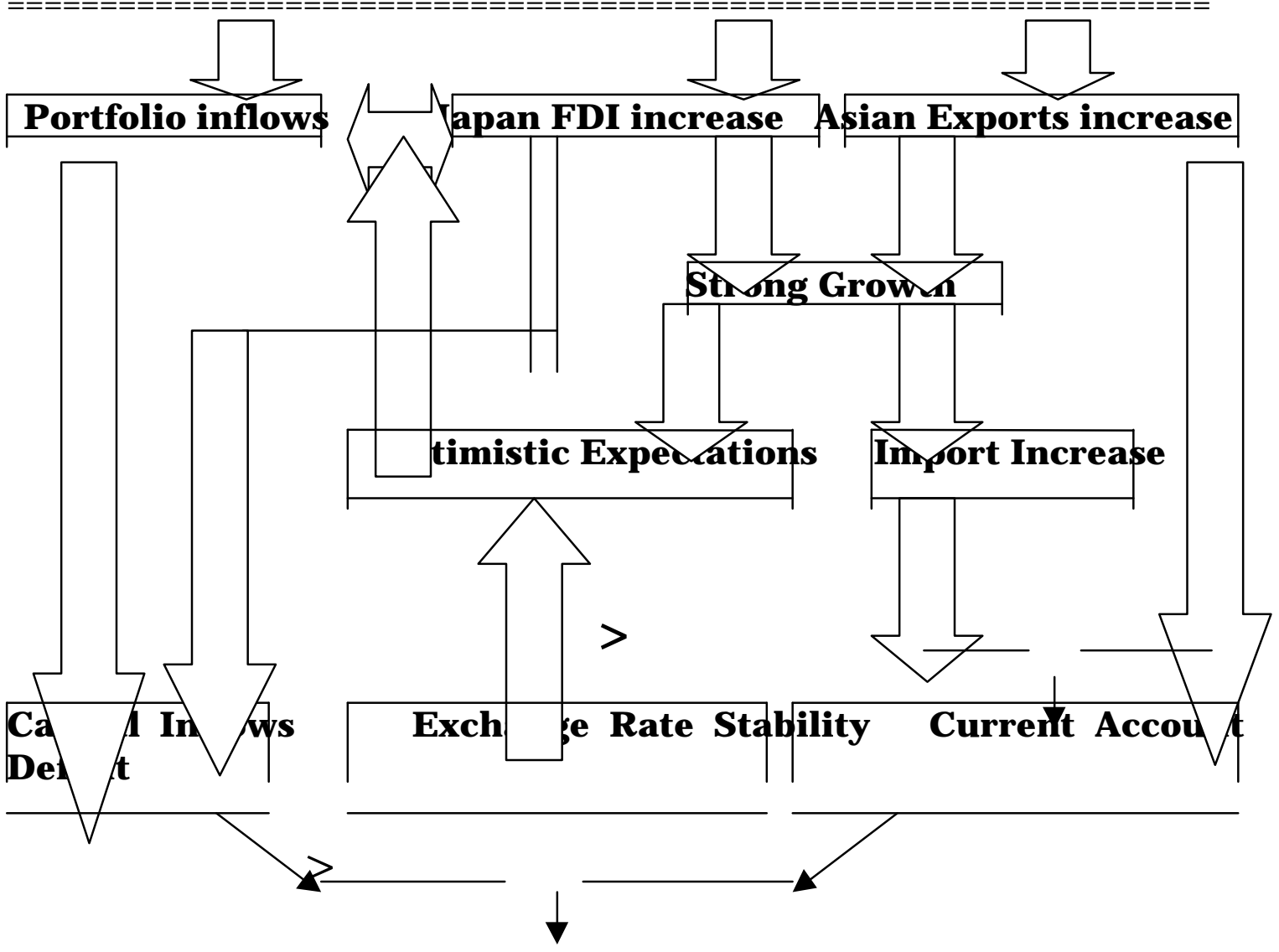

Foreigh Reserves Increase 
Fig. 2 (con'd) Capital Outflow Phase, 1996-98

\section{External Factors}

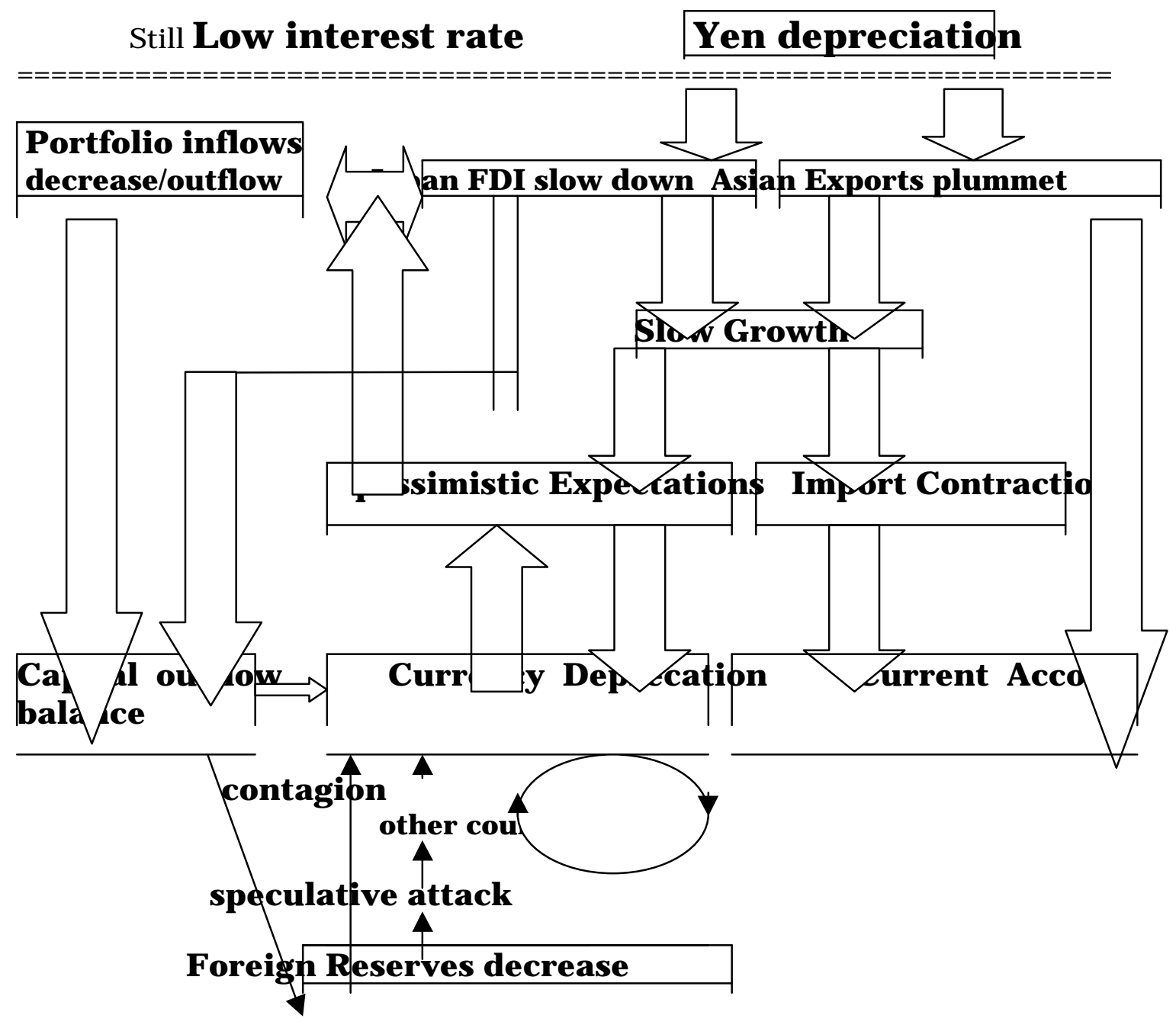


Figure 3: FDI from Japan to Asia and the yen/dollar Rate

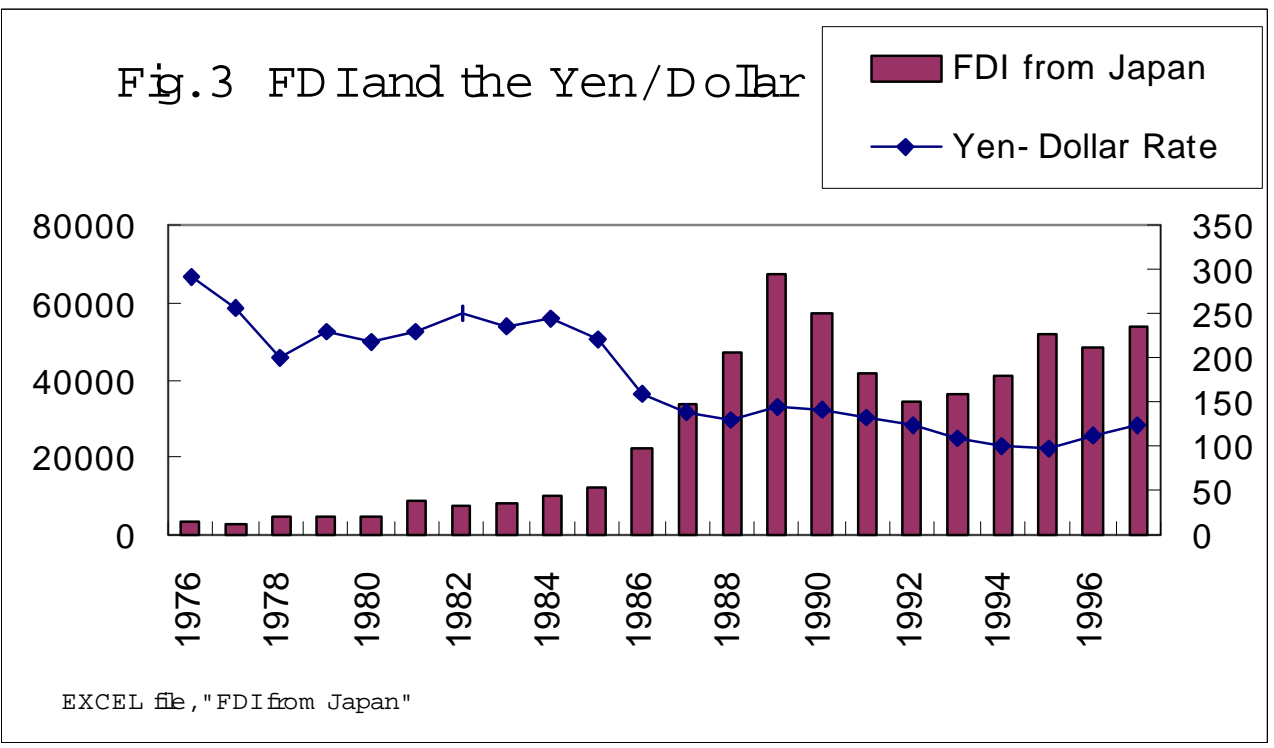




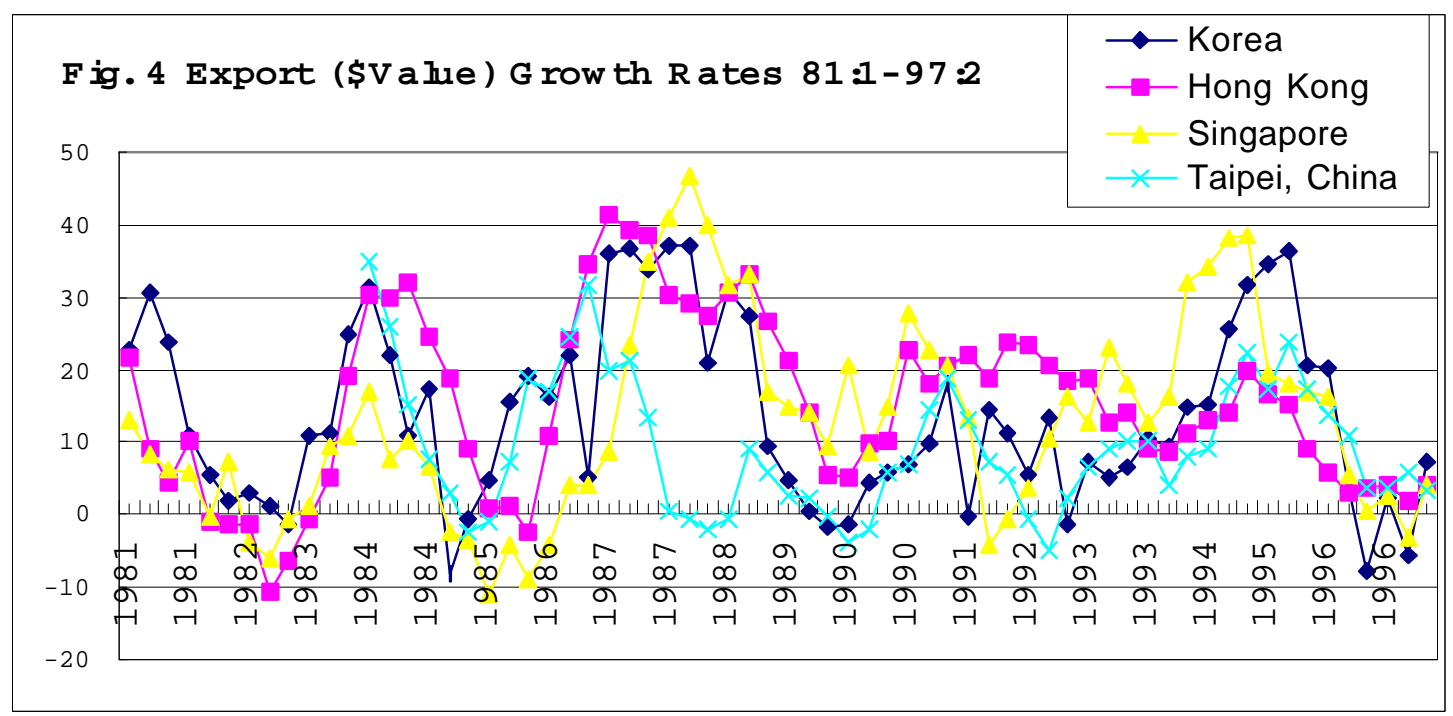




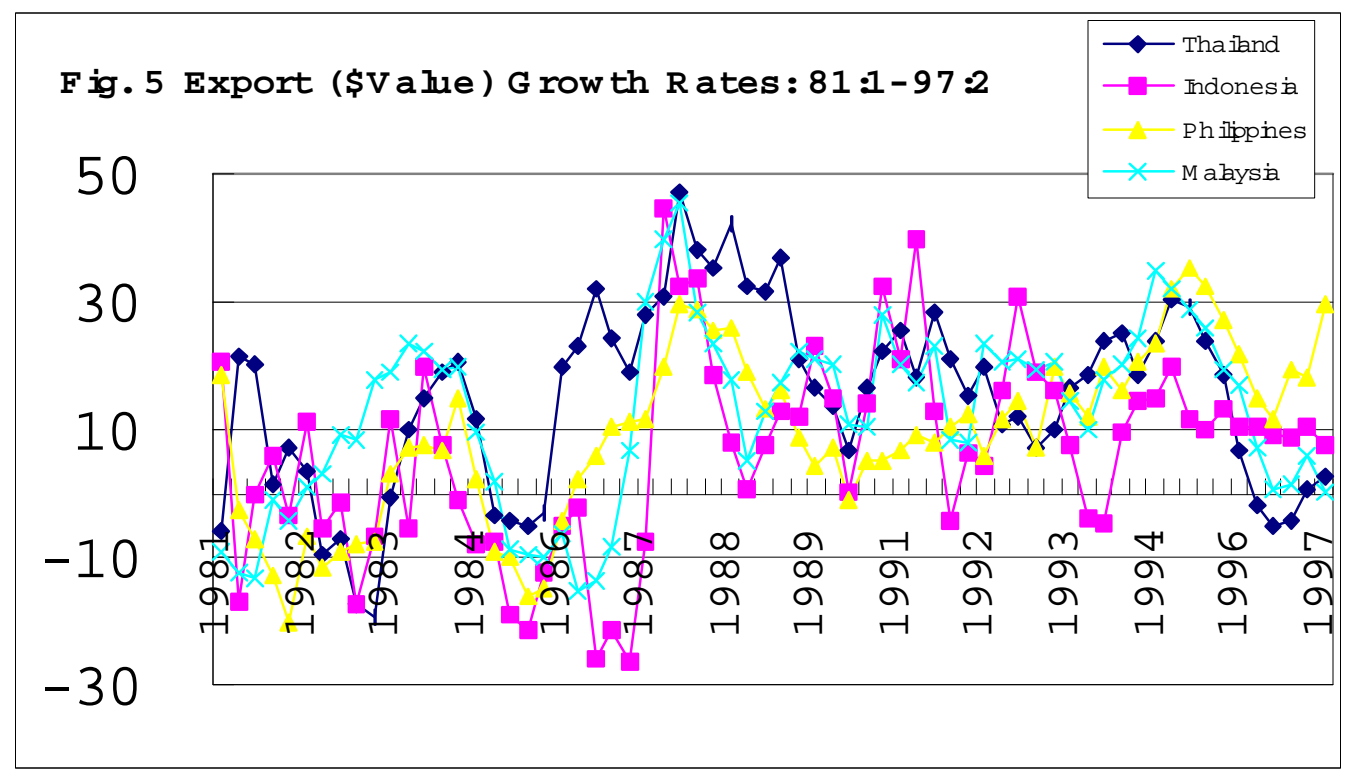


Notes:

${ }^{1}$ An influence of the U.S. interest rate on global capital flows to the emerging markets was pointed out in the Mexican crisis of 1994-95. The declining interest rate in the U.S. from 1992 to 1994 prompted a large capital flows to Latin America and other emerging market economies. The rapid interest rate hike in the United States from February 1994 to the summer of 1994 is pointed out to be one of the many reasons for capital outflows from Mexico, which finally caused the currency devaluation in December 1994.

2 Japanese manufacturing companies shifted their productions also to the North America partly to avoid trade conflicts and to prepare for NAFTA.

${ }^{3}$ Precise definitions of foreign direct investment are different from country to country. Some countries include reinvestment, others do not; Some countries count both the foreign investment and domestic partners' contributions in the case of joint ventures; most countries are on the reporting basis, while China is on the disbursement basis; and for Singapore and Malaysia, only manufacturing sectors are included, while for other countries, all sectors are included. For precise definitions, see the comparative table of definitions in Economic Planning Agency (1998, p. 80). Therefore, numbers are not exactly comparable across countries.

4 These numbers do not necessarily agree with host countries' data presented in Table 2, Panel B. Possible reasons are mentioned in the preceding footnote.

5 The Asian countries in this graph includes, four NIEs, ASEAN-4, China, and other broadly defined Asian countries. The category follows the "Asia" in the Ministry of Finance data source.

${ }^{6}$ For an overview of theory of foreign direct investment and its surge in the 1980 s, see Graham and Krugman (1991, 1993). A seminal work on Japanese FDI is Kojima (1978).

7 Belderbos, et al. examined the determinants of local contents among 157 Japanese electronics manufacturing subsidiaries in Asia. Local contents, the sum of in-house value added and local outsourcing, are considered to be a key for benefits to host countries, as they yield technological transfers. They found that local contents are 
lower in greenfield subsidiaries; subsidiaries of R\&D intensive parents; and export oriented subsidiaries in ASEAN-4 and China. In contrast, local contents are higher in export oriented subsidiaries located in the NIEs; those subsidiaries that have a higher domestic sales ratio; and subsidiaries of a vertical keiretsu firm with strong intrakeiretsu supplier relationships. Urata and Kawai attempts to measure the intra-firm spillovers by comparing total factor productivity changes in the parent and subsidiaries. They found that capability to absorb technologies, reflected in educational level and in experiences in industrial production, in the host countries is very important for them to absorb technological transfer from foreign firms, both in the forms of intra-firm technological transfer and local technological transfers.

8 The major channel to growth from the exchange rate, the Japanese growth and the US growth is considered to be through exports. The East Asian Miracle (The World Bank, 1993) was very much a story of tremendous export growth. In the 1980s and the first half of the 1990s, many economies in Asia achieved sustained export growth of 20 percent or more. Export promotion, instead of import protection, was a successful incentive. All Asian countries, which used to be an agrarian economies only decades ago, rapidly modernized manufacturing firms, and started to export more sophisticated manufactured goods. See Ito (1998) for detailed analysis of Asian export deceleration in 1995-96.

9 The IMF contributed only $\$ 4$ billion for the package, because it is $500 \%$ of the quota of Thailand. The $500 \%$ was considered to be the limit at that time, due to the precedent of Mexican package.

10 I owe Dani Rodrik for suggesting me some of policy implications included in this section. 